\title{
Air Quality Changes and Geospatial Dispersion Modeling in the Dry Season in Port Harcourt and its Environs, Niger Delta, Nigeria
}

\author{
Antai, Raphael Eduk ${ }^{1}$; Osuji, Leo C. ${ }^{2}$; Obafemi, Andrew A. ${ }^{3}$ and Onojake, \\ Mudiaga C. ${ }^{4}$
}

${ }^{1}$ Institute of Natural Resources, Environment and Sustainable Development, University of Port Harcourt, Choba, Nigeria.

${ }^{1}$ Inter - Environments Limited, Rumuodara, Port Harcourt, Nigeria.

${ }^{2,4}$ Department of Pure and Industrial Chemistry, University of Port Harcourt, Choba, Nigeria.

${ }^{3}$ Department of Geography and Environmental Management, University of Port Harcourt, Choba, Nigeria.

Corresponding Author: e-mail: rantai_ralph@yahoo.com. Phone no: +2348037419259, +2349035225368

\begin{abstract}
This work is a geospatial analysis of air dispersion for the purpose of establishing the concentration trend of air pollutants within the study area. Pollutants of consideration are $\mathrm{SO}_{2}, \mathrm{NO}_{2}, \mathrm{CO}, \mathrm{H}_{2} \mathrm{~S}, \mathrm{NH}_{3}, \mathrm{VOCs}, \mathrm{CH}_{4}$, $P M_{2.5}, P M_{10}$, TSP, while area of interest are Port Harcourt, Obio/Akpor, Eleme, Oyigbo, Etche and Ikwerre Local Government Areas. This is an approach to identify the hotspots and how they are dispersed to impact on other parts of the region. This is an attempt to predict future pollution trends, but an approach to gain understanding of the general scenarios of air quality status and how they impact on receptor areas some kilometers away from the hotspot. Pollution hotspots are locations where emissions from specific sources such as water or air pollution may expose local populations to elevated health risks and environment degradation. It indicates areas with strong pollution sources and high industrial activities of adverse effect
\end{abstract}

Keywords-Air Quality Changes, Dry Season, Geospatial, IPPC, Hotspots, Modeling.

\section{INTRODUCTION}

Pollution is defined by the European Union 1996 Council Directive on Integrated Pollution Prevention and Control (IPPC) as "the direct or indirect introduction as a result of human activity, of substances, vibrations, heat or noise into the air, water or land which may be harmful to human health or the quality of the environment, result in damage to material property, or impair or interfere with amenities and other legitimate uses of the environment". Inorganic and organic air pollutants cause negative health and environmental effects such as respiratory ailments, premature deaths. Air pollution-related deaths worldwide are estimated to be up to 2 million per annum.

Other environmental consequences of air pollution include acidification of soil and water and loss of plant and animal life. Air quality assessment studies in Nigeria have focused mainly on urban centres where industrial processes, domestic activities and traffic congestion constitute major sources of air pollution.

Most of these studies are independent as there are no systematic measurements of air quality public agencies. Meteorological parameters influence aids to drive the air pollutants from the pollutant hotpots to non-sources areas (Antai et al., 2017, Everitt, 1992 and Esplin, 1995). This is the trend that has put man in alert in his own environment since the air has no boundary or barrier from one man to another.

The aim of this research is to assess changes in existing physical and chemical characteristic of the air quality and to determine the hotspots and assess the level of concentration of air pollutants dispersion trends in the study area. Results of geospatial analysis and generalized additive models revealed that sources of pollutants in the study areas are both localized in the up-land area and the region around the coastal area.

\section{Description of the Study Area \\ Location}

Port Harcourt metropolis is located between latitudes $4^{0} 35^{\prime}$ and $5^{0} 30^{\prime}$ 'North and between longitudes $6^{\circ} 54^{\prime}$ and $7^{\circ} 08^{\prime}$ East. It covers an estimated area of 1811.6 square kilometer. Port Harcourt, the capital of Rivers State, was established in 1914 by the British colonial administration under Lord 
Lugard to meet the pressing economic needs of the Europe the city, which lies at the heart of the Niger Delta, is one of the world's richest wetlands and is bounded on the south by the Atlantic Ocean, to the North by Imo and Abia States, to the East by Akwa Ibom State and to the West by Bayelsa and
Delta States respectively. The spatial coverage of this study extends through beyond in Port Harcourt and its environs, Port Harcourt, Obio/Akpor, Eleme, Oyibo, Ikwerre and Etche Local Government Areas.

Table.1: Sampling Points Key, Description of Sampling Points, Coordinate and Frequency of Monitoring

\begin{tabular}{|c|c|c|c|c|}
\hline $\begin{array}{l}\text { Sampling } \\
\text { Point } \\
\text { Code: }\end{array}$ & Description of Sampling Points & Coordinates & & $\begin{array}{l}\text { Frequency of } \\
\text { Monitoring/Hourly }\end{array}$ \\
\hline SP 1 & y FLT and FOT Signboard & $\mathrm{N} 04^{0} 43^{\prime} .207^{\prime \prime}$ & E $007^{0} 09^{\prime} .478^{\prime}$ & $\begin{array}{l}\text { Morning, Afternoon and } \\
\text { Evening }\end{array}$ \\
\hline SP 2 & Notore Road by Notore Garden Camp, Onne & $\mathrm{N} 04^{0} 44^{\prime} .147^{\prime}$ & $\mathrm{E} 007^{\circ} 08^{\prime} .526^{\prime}$, & $\begin{array}{l}\text { Morning, Afternoon and } \\
\text { Evening }\end{array}$ \\
\hline SP 3 & $\begin{array}{l}\text { Onne (Trailer park) Junction by East-West } \\
\text { Road }\end{array}$ & $\begin{array}{l}\mathrm{N} 04^{0} 45^{\prime} .510^{\prime}, \\
516^{\prime},\end{array}$ & E $007^{0} 09^{\prime}$ & $\begin{array}{l}\text { Morning, Afternoon and } \\
\text { Evening }\end{array}$ \\
\hline SP 4 & $\begin{array}{l}\text { Port Harcourt Refinery Junction by East-West } \\
\text { Road, Alesa }\end{array}$ & $\begin{array}{l}\mathrm{N} 04^{0} 47^{\prime} .066^{\prime}, \\
001^{\prime},\end{array}$ & $\mathrm{E} 007^{0} 07^{\prime}$ & $\begin{array}{l}\text { Morning, Afternoon and } \\
\text { Evening }\end{array}$ \\
\hline SP 5 & Agbonchia by Zina Motel Junction Eleme & $\mathrm{N} \mathrm{04} 4^{0} 47^{\prime} .867^{\prime}$, & $\mathrm{E} 007^{0} 07^{\prime} .358^{\prime}$ & $\begin{array}{l}\text { Morning, Afternoon and } \\
\text { Evening }\end{array}$ \\
\hline SP 6 & $\begin{array}{l}\text { Eleme Petrochemical (Ndorama gate) Aleto, } \\
\text { Eleme }\end{array}$ & $\mathrm{N} 04^{0} 48^{\prime} .744^{\prime}$, & Е $007^{0} 05^{\prime} .842^{\prime}$, & $\begin{array}{l}\text { Morning, Afternoon and } \\
\text { Evening }\end{array}$ \\
\hline SP 7 & Sandfilled Roundabout, Akpajo & $\mathrm{N} 04^{0} 49^{\prime} .402^{\prime}$ & $\mathrm{E} 007^{0} 05^{\prime} .276^{\prime}$ & $\begin{array}{l}\text { Morning, Afternoon and } \\
\text { Evening }\end{array}$ \\
\hline SP 8 & Okoloma Afam by Afam Power Plant & $\mathrm{N} 04^{0} 51^{\prime} .058^{\prime}$, & Е $007^{0} 15^{\prime} .088^{\prime}$ & $\begin{array}{l}\text { Morning, Afternoon and } \\
\text { Evening }\end{array}$ \\
\hline SP 9 & Izuoma Asa by Dominican College & $\mathrm{N} 04^{0} 51^{\prime} .458^{\prime}$, & $\mathrm{E} 007^{0} 10^{\prime} .717^{\prime}$, & $\begin{array}{l}\text { Morning, Afternoon and } \\
\text { Evening }\end{array}$ \\
\hline SP 10 & Oyigbo by Eke Oyigbo Market & $\mathrm{N} 04^{0} 52^{\prime} .561^{\prime \prime}$ & Е $007^{0} 08^{\prime} .889^{\prime}$ & $\begin{array}{l}\text { Morning, Afternoon and } \\
\text { Evening }\end{array}$ \\
\hline SP 11 & Oyigbo Junction by Port Harcourt-Aba Road & $\mathrm{N} 04^{0} 52^{\prime} .852^{\prime}$ & E $007^{0} 07^{\prime} .959^{\prime}$, & $\begin{array}{l}\text { Morning, Afternoon and } \\
\text { Evening }\end{array}$ \\
\hline SP 12 & $\begin{array}{l}\text { Shell Flow Station/Location Junction, } \\
\text { Umuebulu 4, Etche }\end{array}$ & $\begin{array}{l}\mathrm{N} 04^{0} 53^{\prime} .6107^{\prime} \\
302^{\prime},\end{array}$ & E $007^{0} 07^{\prime}$ & $\begin{array}{l}\text { Morning, Afternoon and } \\
\text { Evening }\end{array}$ \\
\hline SP 13 & Shell Gas Plant, Umuebulu 4, Etche & $\mathrm{N} 04^{0} 53^{\prime} .674^{\prime}$, & E $007^{0} 07^{\prime} 129 ’$ & $\begin{array}{l}\text { Morning, Afternoon and } \\
\text { Evening }\end{array}$ \\
\hline SP 14 & Igbo Etche Junction-Umasikpo, Igbo Etche & $\mathrm{N} 04^{0} 56^{\prime} .788^{\prime}$, & E $007^{0} 04^{\prime} .94 ’$ & $\begin{array}{l}\text { Morning, Afternoon and } \\
\text { Evening }\end{array}$ \\
\hline SP 15 & Eleme Junction by Oilmill Bus Stop & $\begin{array}{l}\mathrm{N} 04^{0} 51^{\prime} .267^{\prime}, \\
843^{\prime \prime}\end{array}$ & $\mathrm{E} 007^{0} 03^{\prime}$ & $\begin{array}{l}\text { Morning, Afternoon and } \\
\text { Evening }\end{array}$ \\
\hline SP 16 & Rumukrushi Bus Stop by Rumukrushi Park & $\begin{array}{l}\mathrm{N} 04^{0} 50^{\prime} .992^{\prime}, \\
201^{\prime \prime}\end{array}$ & E $007^{0} 03^{\prime}$ & $\begin{array}{l}\text { Morning, Afternoon and } \\
\text { Evening }\end{array}$ \\
\hline SP 17 & Rumukrushi Tank by East-West Road & $\begin{array}{l}\mathrm{N} 04^{0} 51^{\prime} .859^{\prime}, \\
364^{\prime},\end{array}$ & $\mathrm{E} 007^{0} 03^{\prime}$ & $\begin{array}{l}\text { Morning, Afternoon and } \\
\text { Evening }\end{array}$ \\
\hline SP18 & Eneka Roundabout, Rumu-olukwu, Eneka & $\begin{array}{l}\mathrm{N} 04^{0} 53^{\prime} .756^{\prime}, \\
392^{\prime},\end{array}$ & $\mathrm{E} 007^{0} 02^{\prime}$ & $\begin{array}{l}\text { Morning, Afternoon and } \\
\text { Evening }\end{array}$ \\
\hline SP 19 & Artillery Junction by Okporo Road & $\begin{array}{l}\mathrm{N} 04^{0} 50^{\prime} .612^{\prime}, \\
298^{\prime},\end{array}$ & $\mathrm{E} 007^{0} 02^{\prime}$ & $\begin{array}{l}\text { Morning, Afternoon and } \\
\text { Evening }\end{array}$ \\
\hline SP 20 & Rumuobiakani Junction by Oginigba/Old Aba & N04 ${ }^{0} 50 ’ .208^{\prime}$ & E $007^{0} 02^{\prime}$ & Morning, Afternoon and \\
\hline
\end{tabular}


Road

SP 21 Rumuomasi in- Between Aba Road

Rumuomasi Junction and Old Aba Road

SP 22 Rumuodara Junction by East-West Road

SP 23 Eliozu Flyover Junction

SP24 Rukpokwu Roundabout

SP 25 Igwuruta Roundabout by Air Port Road

SP 26 Port Harcourt International Air Port

Junction/Roundabout Omagwa

SP 27 Greater Port Harcourt in-Between Air Port and Obirikwere Road by $\mathrm{H}$ and $\mathrm{H}$ Engineering Ltd

SP 28 Aluu Roundabout, Aluu

SP 29 Choba Junction, By Uniport East-West Road

SP $30 \quad$ Rumuosi Junction by East-West Road

SP $31 \quad$ Nkpolu Junction by East-West Road

SP 32 Rumuokoro Junction/Roundabout

SP 33 Wimpy Junction by Ikwere Road

SP 34 Location Junction by NTA and Ada George

Road

SP 35 Rumuokuta Junction/ Roundabout

SP 36 Rumuigbo by Obiwali Junction

SP 37 Akar Base, Saipem Gate, Rumuolumeni

SP38 University of Education's Gate, Rumuolumeni

SP 39 Eagle Island Gate by Illoabuchi T Junction

SP40 Agip Junction by Agip Flyover

SP41 Mile 3 by Mile 3 Park

SP 42 Illoabuchi by Ukuoto Street, Mile 2

SP 43 Ikoku by Eko Bank

SP 44 Waterline Junction by Olu Obansanjo/Port Harcourt Aba Road

\begin{tabular}{|c|c|}
\hline $066^{\prime \prime}$ & \\
\hline N 04050'. 236”, & E $007^{0} 01^{\prime} 548^{\prime}$ \\
\hline $\mathrm{N} 04^{0} 51^{\prime} .622^{\prime \prime}$ & E $007^{\circ} 01^{\prime} 776^{\prime \prime}$ \\
\hline $\begin{array}{l}\mathrm{N} 04^{0} 51^{\prime} .570^{\prime \prime} \\
307^{\prime},\end{array}$ & E $007^{0} 01^{\prime}$. \\
\hline $\begin{array}{l}\mathrm{N} 04^{0} 53^{\prime} .447^{\prime}, \\
140^{\prime},\end{array}$ & E $007^{0} 00^{\prime}$. \\
\hline $\begin{array}{l}\mathrm{N} 04^{0} 57^{\prime} .400^{\prime \prime} \\
690^{\prime},\end{array}$ & E $007^{0} 00^{\prime}$. \\
\hline $\begin{array}{l}\text { N } 04^{0} 58^{\prime} .858^{\prime}, \\
989^{\prime},\end{array}$ & E $006^{0} 56^{\prime}$. \\
\hline $\begin{array}{l}\mathrm{N} 04^{0} 57^{\prime} .421^{\prime \prime}, \\
965^{\prime},\end{array}$ & E $006^{0} 56^{\prime}$. \\
\hline N $04^{0} 56^{\prime} .019$ ', & E $006^{0} 56^{\prime} .547^{\prime \prime}$ \\
\hline
\end{tabular}

N 04 53'. 917'" E $006^{0} 54^{\prime} .400$ ',

N $04^{0} 52^{\prime} .951 '$ 'E $006^{0} 56^{\prime} .461^{\prime \prime}$

N $04^{0} 52^{\prime} .158^{\prime \prime}$ E $006^{0} 58^{\prime} .862$ '

N 040 52'. 612', E $006^{0}$ 59'. 855',

N $04^{0} 49^{\prime} .835^{\prime}$ ' E $006^{0} 58^{\prime} .924$ '

$\mathrm{N} 04^{0} 51^{\prime} .137^{\prime \prime}$ E $006^{0} 58^{\prime} .516^{\prime \prime}$

N $04^{0}$ 50'. 271', E $006^{0}$ 59'. 308',

N 040 50'. 843', E $006^{0} 59^{\prime} .421$ ',

N $04^{0} 46^{\prime} .550$ ' E $006^{0} 58^{\prime} .013^{\prime \prime}$

N $04^{0} 48^{\prime} .4200^{\prime \prime}$ E $006^{0} 56^{\prime} .061$ ',

N $04^{0} 47^{\prime} .164$ ' ' E $006^{0} 58^{\prime} .806$ '

N 04 $48^{\prime} .825 '$ E $006^{0} 59^{\prime} .018$ '

N 040 48'. 158', E $006^{0}$ 59'. 409',

$\mathrm{N} 04^{0} 47^{\prime} .451^{\prime \prime}$ E $006^{0}$ 59'. 279',

N 04 48'. 043', E 006 59'. 698',

N 040 49'. 016'" E $007^{0} 00^{\prime} .562$ ',
Evening

ISSN: 2456-1878

Morning, Afternoon and

Evening

Morning, Afternoon and

Evening

Morning, Afternoon and

Evening

Morning, Afternoon and

Evening

Morning, Afternoon and

Evening

Morning, Afternoon and

Evening

Morning, Afternoon and

Evening

Morning, Afternoon and

Evening

Morning, Afternoon and

Evening

Morning, Afternoon and

Evening

Morning, Afternoon and

Evening

Morning, Afternoon and

Evening

Morning, Afternoon and

Evening

Morning, Afternoon and

Evening

Morning, Afternoon and

Evening

Morning, Afternoon and

Evening

Morning, Afternoon and

Evening

Morning, Afternoon and

Evening

Morning, Afternoon and

Evening

Morning, Afternoon and Evening

Morning, Afternoon and Evening

Morning, Afternoon and

Evening

Morning, Afternoon and

Evening

Morning, Afternoon and Evening 


\begin{tabular}{|c|c|c|c|c|}
\hline SP 45 & $\begin{array}{l}\text { Garrison Junction by Ogunabali/Port Harcourt } \\
\text { Aba Road }\end{array}$ & $\mathrm{N} 04^{0} 48^{\prime} 335^{\prime \prime}$ & E $007^{0} 00^{\prime} .566^{\prime \prime}$ & $\begin{array}{l}\text { Morning, Afternoon and } \\
\text { Evening }\end{array}$ \\
\hline SP 46 & $\begin{array}{l}\text { Rumuola Junction/Flyover by Port Harcourt } \\
\text { Aba Road }\end{array}$ & $\mathrm{N} 04^{0} 49^{\prime} .945^{\prime}$, & E $007^{0} 00^{\prime} .315^{\prime}$, & $\begin{array}{l}\text { Morning, Afternoon and } \\
\text { Evening }\end{array}$ \\
\hline SP 47 & Woji by Woji Town Hall & $\begin{array}{l}\mathrm{N} 04^{0} 49^{\prime} .820^{\prime}, \\
018^{\prime},\end{array}$ & E $007^{0} 03$, & $\begin{array}{l}\text { Morning, Afternoon and } \\
\text { Evening }\end{array}$ \\
\hline SP 48 & YKC Junction, Woji & N 04 49'. 338', & E $007^{0} 03^{\prime} .228^{\prime}$ & $\begin{array}{l}\text { Morning, Afternoon and } \\
\text { Evening }\end{array}$ \\
\hline SP 49 & Elelenwo by Woji T-Junction/Health Center & $\begin{array}{l}\mathrm{N} 04^{0} 49^{\prime} .807^{\prime}, \\
279^{\prime},\end{array}$ & E $007^{0} 04^{\prime}$ & $\begin{array}{l}\text { Morning, Afternoon and } \\
\text { Evening }\end{array}$ \\
\hline SP 50 & $\begin{array}{l}\text { Trans-amadi by Slaughter Junction/ } \\
\text { Roundabout }\end{array}$ & $\mathrm{N} 04^{0} 48^{\prime} .760^{\prime}$, & E $007^{0} 02^{\prime} 688^{\prime}$ & $\begin{array}{l}\text { Morning, Afternoon and } \\
\text { Evening }\end{array}$ \\
\hline SP 51 & Gbalajam & $\mathrm{N} 04^{0} 48^{\prime} .713^{\prime}$ & E $007^{0} 04^{\prime} .208^{\prime}$ & $\begin{array}{l}\text { Morning, Afternoon and } \\
\text { Evening }\end{array}$ \\
\hline SP 52 & Mothercat Junction, Trans-amadi & $\begin{array}{l}\mathrm{N} 04^{0} 48^{\prime} .304^{\prime}, \\
683^{\prime},\end{array}$ & E $007^{0} 01^{\prime}$. & $\begin{array}{l}\text { Morning, Afternoon and } \\
\text { Evening }\end{array}$ \\
\hline SP53 & $\begin{array}{l}\text { Trans-amadi Gas Turbine by Total E \& P Back } \\
\text { Gate }\end{array}$ & $\begin{array}{l}\text { N 040 49'.003', } \\
834^{\prime \prime}\end{array}$ & $\mathrm{E} 007^{0} 01^{\prime}$ & $\begin{array}{l}\text { Morning, Afternoon and } \\
\text { Evening }\end{array}$ \\
\hline SP 54 & $\begin{array}{l}\text { Abuloma Jetty Road by Okuru Link Road, } \\
\text { Abuloma }\end{array}$ & $\begin{array}{l}\mathrm{N} 04^{0} 46^{\prime} .930^{\prime}, \\
277^{\prime},\end{array}$ & E $007^{0} 03$ & $\begin{array}{l}\text { Morning, Afternoon and } \\
\text { Evening }\end{array}$ \\
\hline SP55 & $\begin{array}{l}\text { Sansung Roundabout/Junction by Peter Odilli } \\
\text { Road }\end{array}$ & $\begin{array}{l}\mathrm{N} 04^{0} 47^{\prime} .728^{\prime}, \\
316^{\prime \prime}\end{array}$ & E $007^{0} 02^{\prime}$ & $\begin{array}{l}\text { Morning, Afternoon and } \\
\text { Evening }\end{array}$ \\
\hline SP 56 & Nkpogu Junction, Trans-amadi & $\begin{array}{l}\text { N } 04^{0} 48^{\prime} 570^{\prime}, \\
994^{\prime},\end{array}$ & E $007^{0} 00^{\prime}$ & $\begin{array}{l}\text { Morning, Afternoon and } \\
\text { Evening }\end{array}$ \\
\hline SP 57 & Eastern By Pass Roundabout/Junction & $\begin{array}{l}\text { N } 04^{0} 47^{\prime} .583^{\prime}, \\
948^{\prime},\end{array}$ & E $007^{0} 00^{\prime}$. & $\begin{array}{l}\text { Morning, Afternoon and } \\
\text { Evening }\end{array}$ \\
\hline SP 58 & Abonnema Jetty by Shell Kidney Island & $\begin{array}{l}\mathrm{N} 04^{0} 46^{\prime} .583^{\prime}, \\
315^{\prime},\end{array}$ & E $007^{0} 00^{\prime}$ & $\begin{array}{l}\text { Morning, Afternoon and } \\
\text { Evening }\end{array}$ \\
\hline SP 59 & $\begin{array}{l}\text { Tombia Extension by Prof Abowie GRA Phase } \\
\text { II }\end{array}$ & $\begin{array}{l}\text { N } 04^{0} 49^{\prime} .509^{\prime}, \\
454^{\prime},\end{array}$ & Е $006^{0} 59^{\prime}$. & $\begin{array}{l}\text { Morning, Afternoon and } \\
\text { Evening }\end{array}$ \\
\hline SP 60 & $\begin{array}{l}\text { King Perekule Junction by Evo street GRA } \\
\text { Phase II }\end{array}$ & N 04049'. 171', & E $007^{0} 00^{\prime} .070^{\prime}$, & $\begin{array}{l}\text { Morning, Afternoon and } \\
\text { Evening }\end{array}$ \\
\hline SP 61 & Mile 1 Opposite Isaac Boro Park & $\begin{array}{l}\mathrm{N} 04^{0} 47^{\prime} .237^{\prime}, \\
229^{\prime},\end{array}$ & E $007^{0} 00^{\prime}$ & $\begin{array}{l}\text { Morning, Afternoon and } \\
\text { Evening }\end{array}$ \\
\hline SP 62 & Rumuibekwe by Gram Diagnostic Laboratory & $\begin{array}{l}\mathrm{N} 04^{0} 50^{\prime} .375^{\prime}, \\
003^{\prime},\end{array}$ & Е $007^{0} 03^{\prime}$. & $\begin{array}{l}\text { Morning, Afternoon and } \\
\text { Evening }\end{array}$ \\
\hline SP 63 & Stadium Road by Mummy B Junction & $\begin{array}{l}\mathrm{N} 04^{0} 49^{\prime} .615^{\prime}, \\
930^{\prime},\end{array}$ & E $007^{0} 00^{\prime}$ & $\begin{array}{l}\text { Morning, Afternoon and } \\
\text { Evening }\end{array}$ \\
\hline SP 64 & BMSH Junction Old GRA & $\begin{array}{l}\text { N } 04^{0} 46^{\prime} .817^{\prime}, \\
905^{\prime}\end{array}$ & E $007^{0} 00^{\prime}$. & $\begin{array}{l}\text { Morning, Afternoon and } \\
\text { Eveningv }\end{array}$ \\
\hline SP 65 & $\begin{array}{l}\text { Moscow Road by NNPC/House of Assembly } \\
\text { Complex }\end{array}$ & $\begin{array}{l}\mathrm{N} 04^{0} 46^{\prime} .159^{\prime}, \\
166^{\prime}\end{array}$ & $\mathrm{E} 007^{0} 01^{\prime}$ & $\begin{array}{l}\text { Morning, Afternoon and } \\
\text { Evening }\end{array}$ \\
\hline SP66 & Lagos Bus Stop, Town, Port Harcourt & $\begin{array}{l}\mathrm{N} 04^{0} 45^{\prime} .697^{\prime}, \\
132^{\prime},\end{array}$ & $\mathrm{E} 007^{0} 01$ & $\begin{array}{l}\text { Morning, Afternoon and } \\
\text { Evening }\end{array}$ \\
\hline SP 67 & UPE Junction, Borokiri, Port Harcourt & $\begin{array}{l}\mathrm{N} 04^{0} 44^{\prime} .930^{\prime}, \\
489^{\prime},\end{array}$ & E $007^{0} 02^{\prime}$. & $\begin{array}{l}\text { Morning, Afternoon and } \\
\text { Evening }\end{array}$ \\
\hline
\end{tabular}




\begin{tabular}{|c|c|c|c|c|}
\hline SP 68 & Nembe Water Side, Port Harcourt & $\begin{array}{l}\mathrm{N} 0^{0} 45^{\prime} .500^{\prime \prime} \\
361,\end{array}$ & $\mathrm{E} 0007^{0} 01^{\prime}$ & $\begin{array}{l}\text { Morning, Afternoon and } \\
\text { Evening }\end{array}$ \\
\hline SP 69 & $\begin{array}{l}\text { Ibeto Cement Gate, Bundu Ama Estate, Port } \\
\text { Harcourt }\end{array}$ & $\begin{array}{l}\text { N } 04^{0} 44^{\prime} .879^{\prime}, \\
379^{\prime \prime}\end{array}$ & E $007^{0} 00^{\prime}$ & $\begin{array}{l}\text { Morning, Afternoon and } \\
\text { Evening }\end{array}$ \\
\hline SP70 & Makobar Area, Town, Port Harcourt & $\begin{array}{l}\mathrm{N} 04^{0} 45^{\prime} .509^{\prime} \\
533^{\prime}\end{array}$ & E $007^{0} 00^{\prime}$. & $\begin{array}{l}\text { Morning, Afternoon and } \\
\text { Evening }\end{array}$ \\
\hline SP 71 & $\begin{array}{l}\text { Agudama Avenue Junction D/Line, Port } \\
\text { Harcourt }\end{array}$ & $\begin{array}{l}\mathrm{N} 04^{0} 48^{\prime} .367^{\prime}, \\
166^{\prime \prime}\end{array}$ & Е $007^{0} 00^{\prime}$ & $\begin{array}{l}\text { Morning, Afternoon and } \\
\text { Evening }\end{array}$ \\
\hline
\end{tabular}

\section{METHOOLOGY}

A total number of seventy one (71) sampling points (Table 1) were selected in Port Harcourt and its environs using WHO's (2005) guideline for site selection studies for population density, topography, industrial clusters, and heavy traffic.

All the sampling points selected were geo-referenced using GPS model 76Cx Garmin Global positioning system.

Field observations were carried out visually and recorded in the field notebook. Camera was used to take photographs to show evidence of important features and activities that may be the primary sources of the air pollutants.

\section{Validity/Reliability of Instrument}

All the portable in-situ meters for the field air quality and meteorological parameters including noise level measurement were certified calibrated by the manufacturer prior to mobilization to the field data gathering. Quality assurance and control measures were carried out accurately as per the equipment manufacturer's directive and battery were fully charged.

\section{Pollutant Mapping}

Concentration levels at each location were mapped out using ArcGIS 10.2 software. The software integrated the spatial air pollutants data from the sampling points within the Port Harcourt and its environs and analyzed them as input variables for graphical presentation to produce curves or contours of air pollutants levels.

\section{RESULTS AND INTERPRETATION} Distribution of $\mathrm{SO}_{2}$ in Study Area in the Dry Season In the dry season, $\mathrm{SO}_{2}$ hotspot is visible within Eleme with the highest concentration within 1.10 to $1.18 \mathrm{ppm}$ (Figure 1). It occupies an aerial coverage of about 3,725meters radius. It has a larger influence on Port Harcourt, followed by Obio/Akpor and Oyigbo while its minor influence is in Ikwerre as shown in Figure 1. Its least influence is on Etche area. It is predicted that the hotspot will contribute about $0.035 \mathrm{ppm}$ to $0.080 \mathrm{ppm}$ to the background concentration of $\mathrm{SO}_{2}$ in parts of Port Harcourt, Obio/Akpor, Oyigbo, Etche and Ikwerre Local Government Areas respectively. 


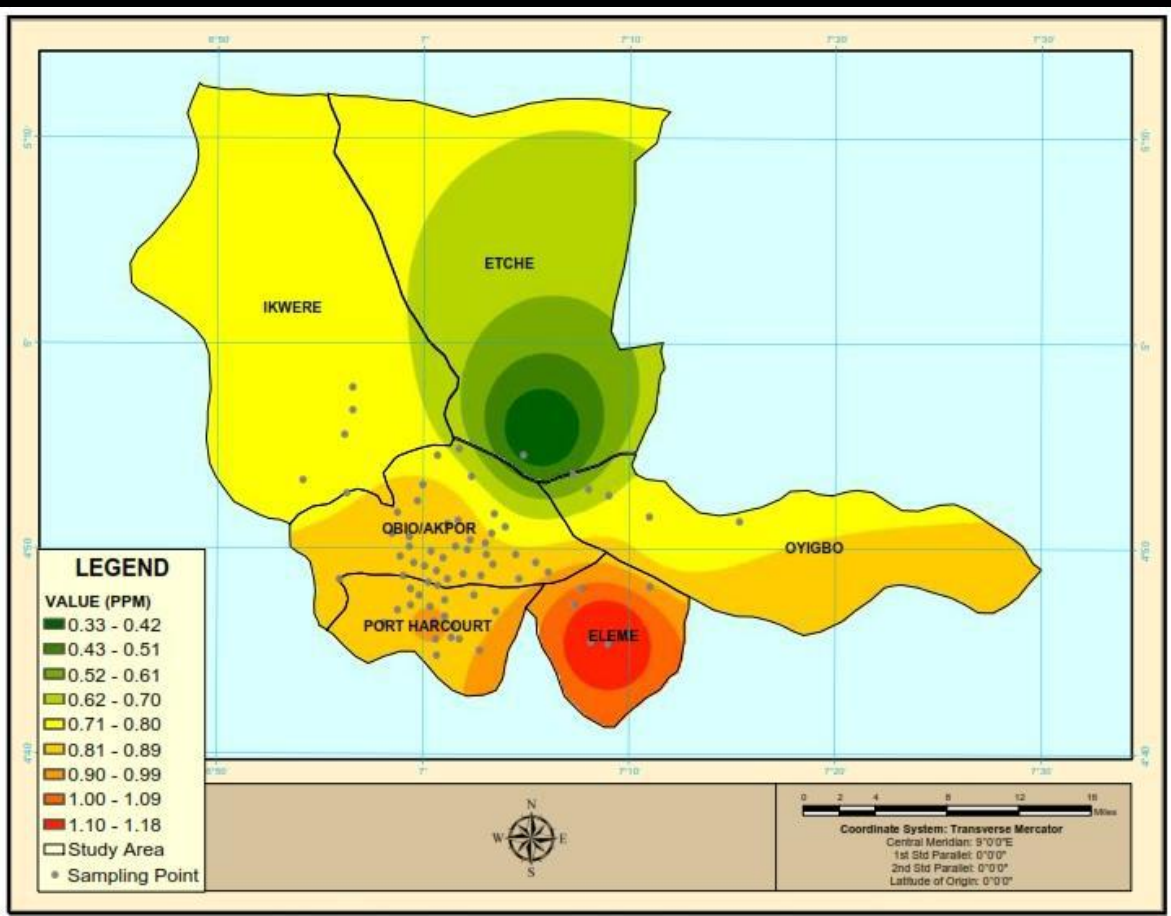

Fig.1: Distribution in $\mathrm{SO}_{2}$ of the Study Area in the Dry Season

\section{Distribution of $\mathrm{NO}_{2}$ in the Study Area in the Dry Season}

In the dry season, $\mathrm{NO}_{2}$ hotspots are visible within Eleme and part of Oyigbo with the highest concentration within 0.82 to $0.88 \mathrm{ppm}$ (Figure 2). It occupies elongated area coverage of about 17670meters. It showed moderate influence in Obio/Akpor and Ikwerre It has a larger influence on Oyigbo followed by Etche with the least influence in Port Harcourt area as shown in Figure 2. It is predicted that these hotspots will contribute about 0.05 to $0.070 \mathrm{ppm}$ to the background concentration of $\mathrm{NO}_{2}$ in parts of Oyigbo, Etche, Obio/Akpor, Port Harcourt and Ikwerre.

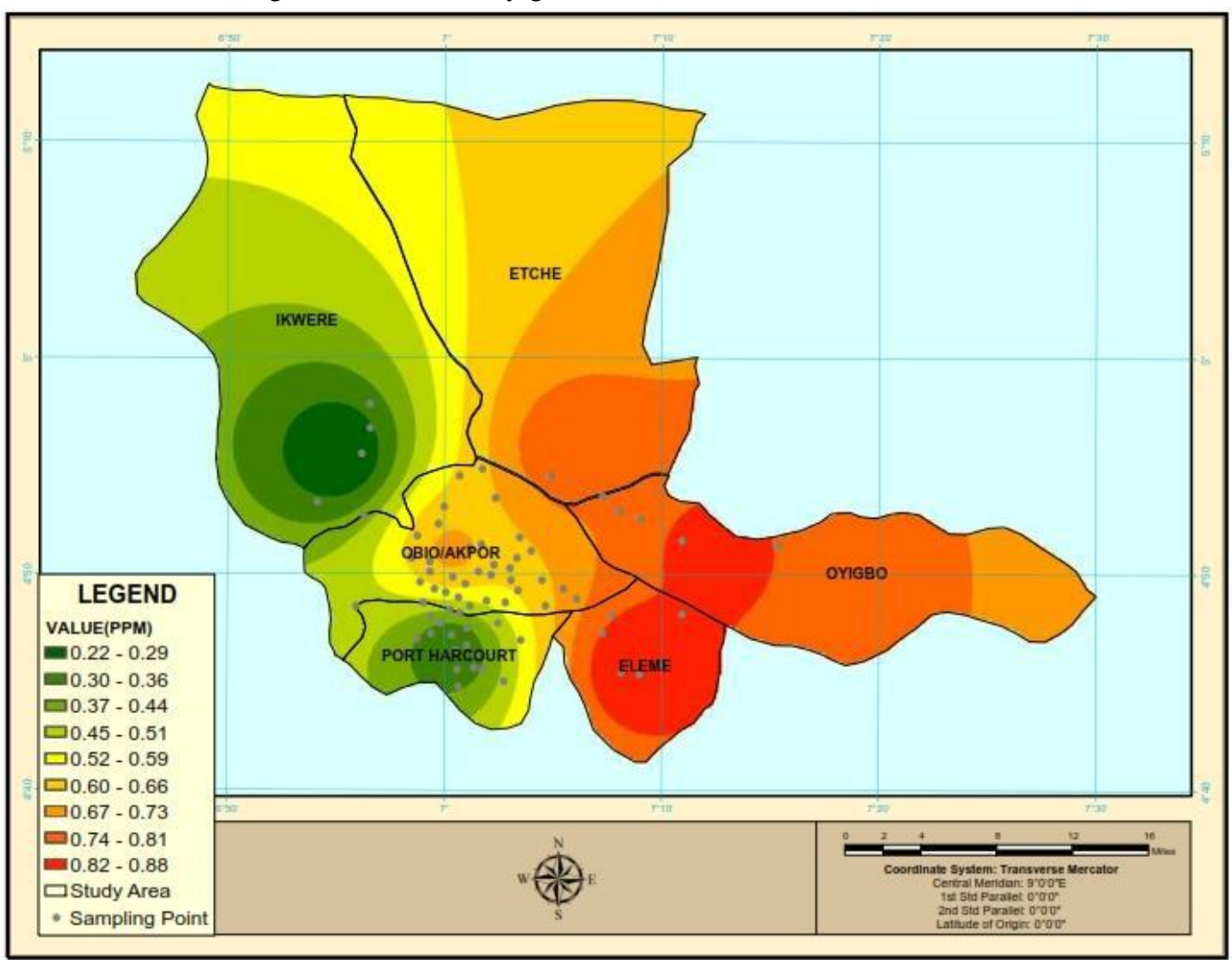


Fig.2: Distribution of $\mathrm{NO}_{2}$ in the Study Area in the Dry Season

\section{Distribution of $\mathrm{H}_{2} \mathrm{~S}$ in the Study Area in the Dry Season} In the dry season, $\mathrm{H}_{2} \mathrm{~S}$ hotspot is visible within Eleme with the highest concentration within 1.70 to $1.87 \mathrm{ppm}$ as shown in Figure 3. It occupies an aerial coverage with a 2670 meters radius and has a moderate influence on Oyigbo and its least influence is in Port Harcourt, Obio/Akpor and Etche. It is predicted that this hotspot will contribute additional 0.05 to $0.1 \mathrm{ppm}$ to the background concentration of $\mathrm{H}_{2} \mathrm{~S}$ in parts of Port Harcourt, Oyigbo, Obio/Akpor and Etche.

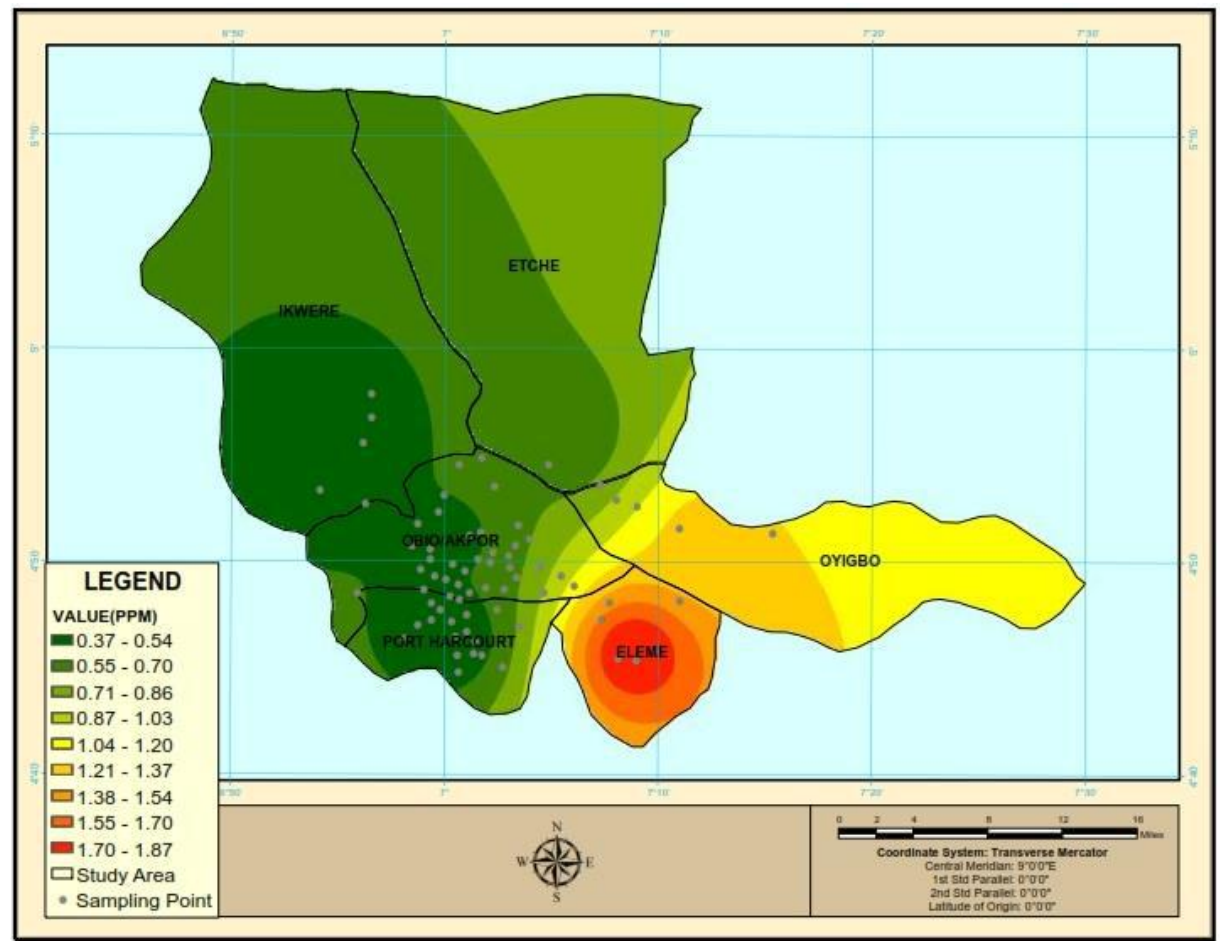

Fig.3: Distribution of $\mathrm{H}_{2} \mathrm{~S}$ in the Study Area in the Dry Season

Distribution of VOCs in the Study Area in the Dry Season

In the dry season, VOCs hotspot is visible within Eleme with the highest concentration within 6.26 to $6.82 \mathrm{ppm}$ as shown in Figure 4. It occupies an aerial coverage of about 3,850meters radius. It has a larger influence on Obio/Akpor. It has least influence on Port Harcourt, followed by Oyigbo, Etche and Ikwerre LGAs. It is estimated that this hotspot will contribute additional $0.25 \mathrm{ppm}$ to $0.41 \mathrm{ppm}$ to the background concentration of VOCs.

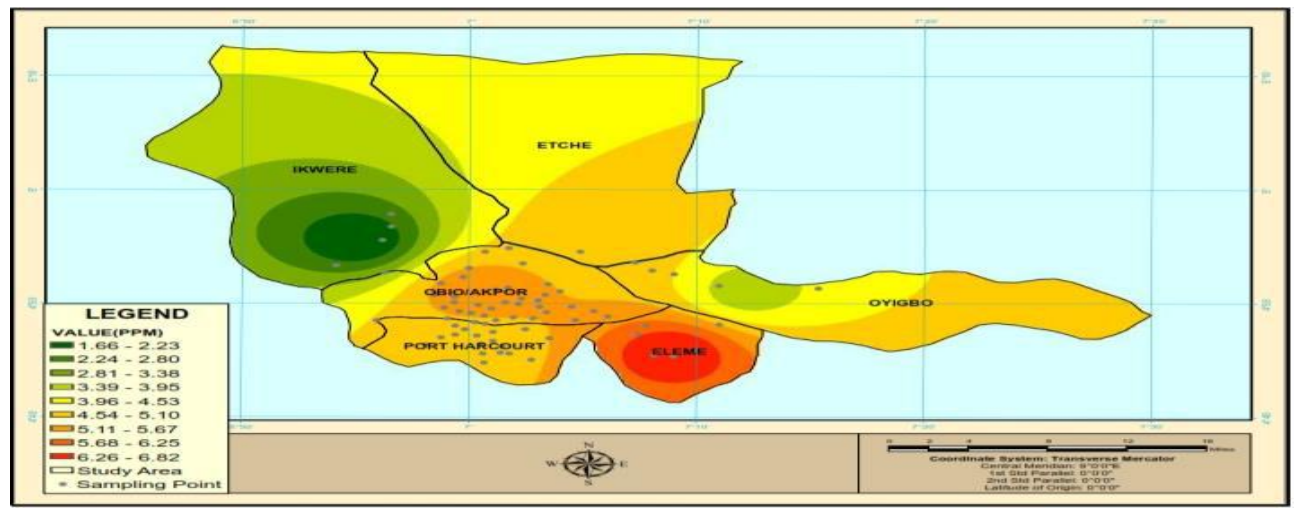

Fig.4: Distribution of VOCs in the Study Area in the Dry Season 


\section{Distribution of CO in the Study Area in the Dry Season}

In the dry season, Carbon Monoxide (CO) hotspot is visible within Eleme with highest concentration within 25.06 to $27.85 \mathrm{ppm}$ as shown in Figure 5. It occupies an aerial coverage with a 4350 meters radius. It has a minor influence on Obio/Akpor, followed by Oyigbo and Port Harcourt. Its least influence is on Ikwerre and Etche areas. It is predicted that this hotspot contributes additional 1.1 to $2.05 \mathrm{ppm}$ to the background concentration of carbon monoxide in parts of Obio/Akpor, followed by Oyigbo and Port Harcourt.

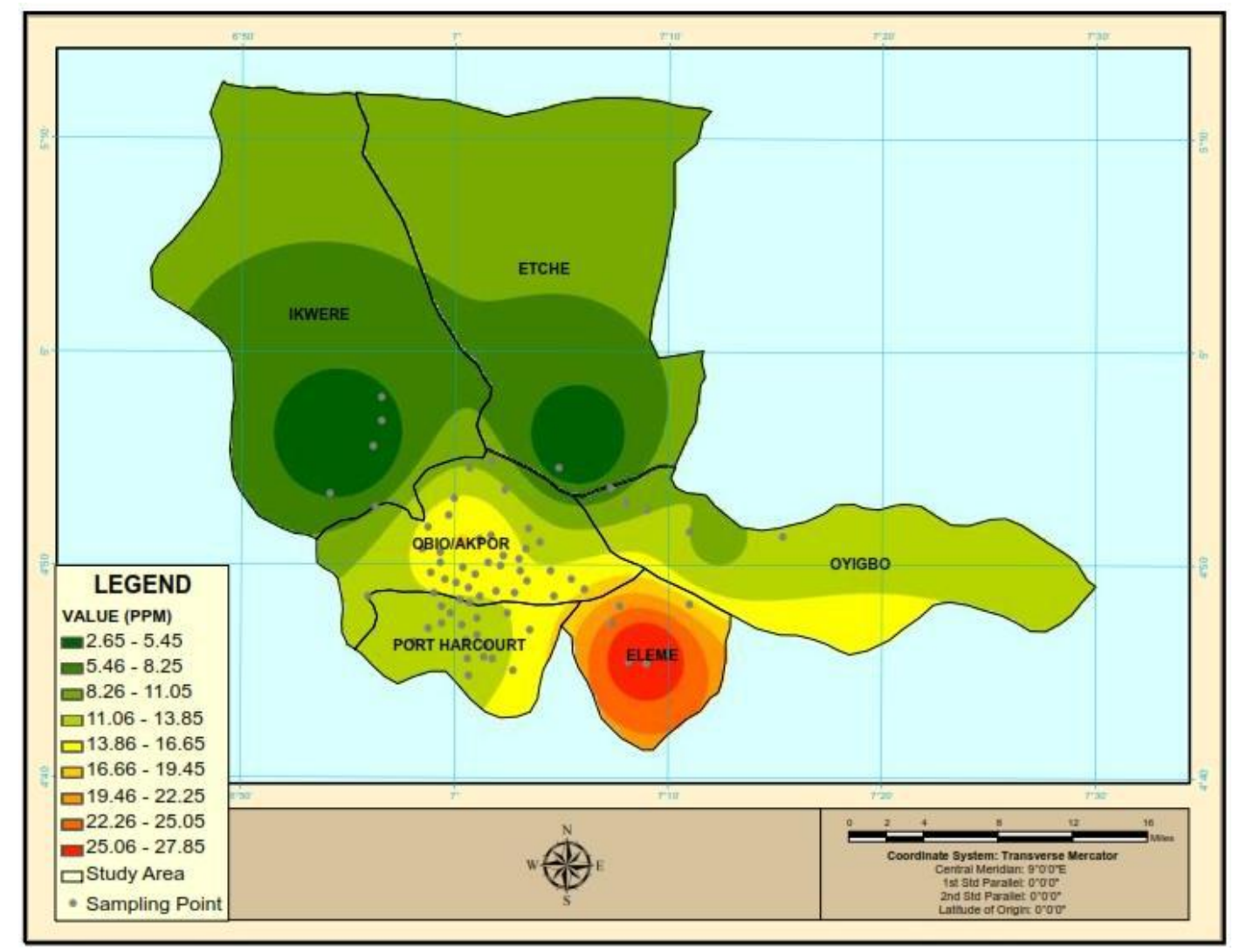

Fig.5: Distribution of CO in the Study Area in the Dry Season

\section{Distribution of $\mathrm{NH}_{3}$ in the Study Area in the Dry Season}

In the dry season, ammonia hotspot is visible within Eleme with highest concentration within 5.32 to $5.98 \mathrm{ppm}$ as shown Figure 6. It occupies an aerial coverage of 3500meters radius. It has a very minor influence on Oyigbo, but less on Obio/Akpor and Port Harcourt. Its least influence is on
Ikwerre and Etche areas. It is predicted that this hotspot will contribute additional 0.15 to $0.2 \mathrm{ppm}$ to the background concentration of ammonia in parts of Oyigbo, Obio/Akpor and Port Harcourt. 


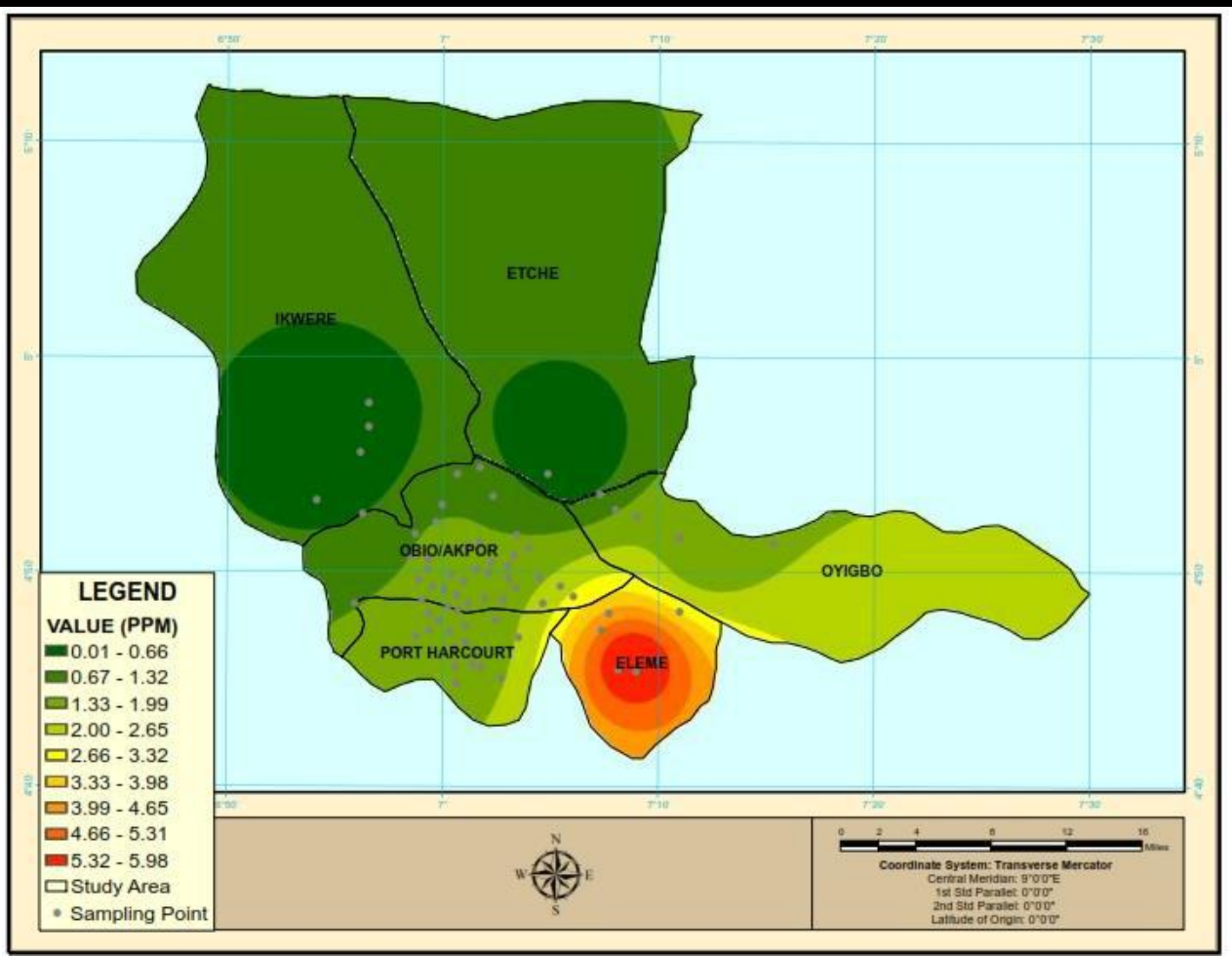

Fig.6: Distribution of $\mathrm{NH}_{3}$ in the Study Area in the Dry Season

\section{Distribution of $\mathrm{CH}_{4}$ in the Study Area in the Dry Season} In the dry season, methane hotspots are visible within Eleme followed by Obio/Akpor and Port Harcourt with highest concentration within 6.86 to $7.48 \mathrm{ppm}$ as shown in Figure 7. It occupies an aerial coverage of 3750 meters radius. It has a moderate influence on Oyigbo. It has least influence on Ikwerre and Etche LGAs. It is predicted that these hotspots contribute about 3.0 to $4.0 \mathrm{ppm}$ to the background concentration of methane $\left(\mathrm{CH}_{4}\right)$ in parts of Oyigbo, Ikwerre and Etche.

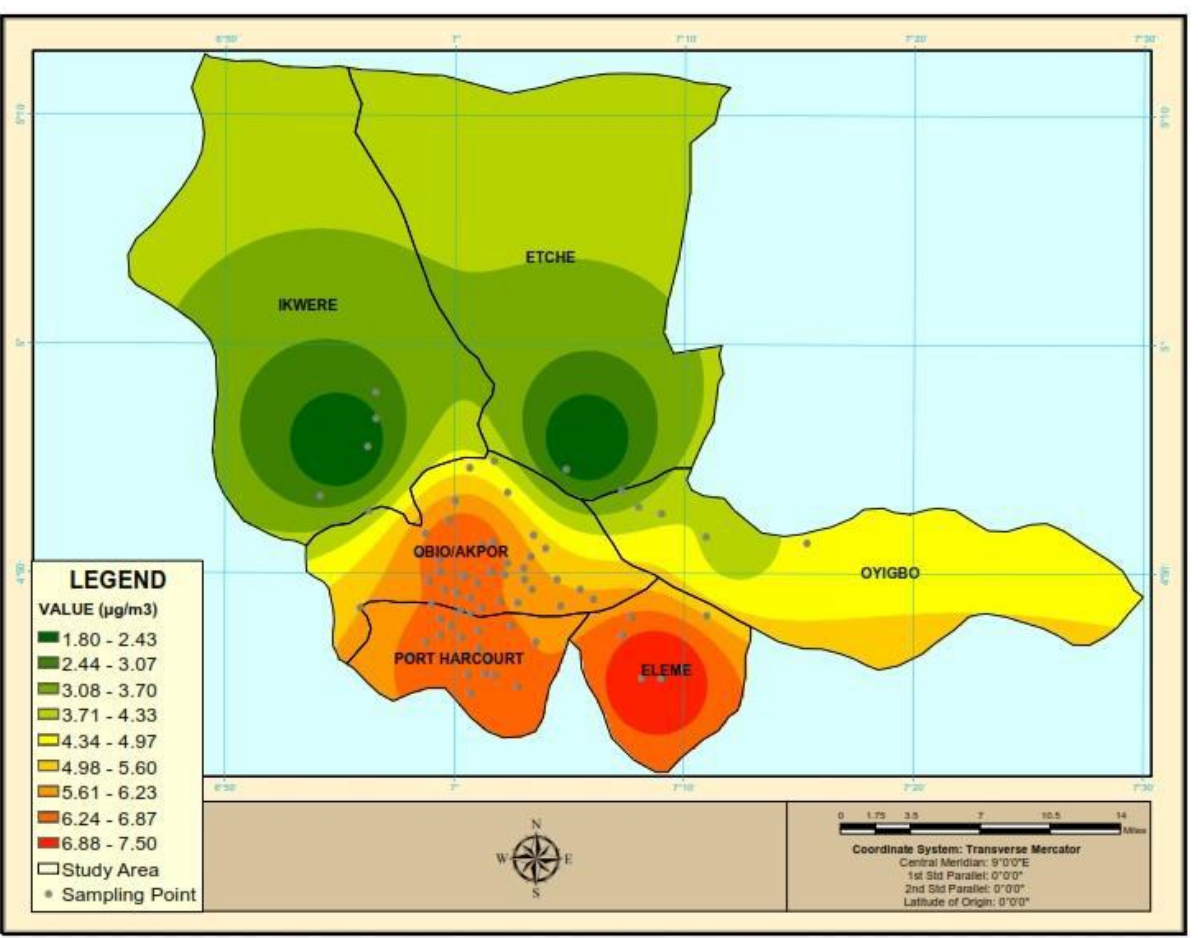

CH4 MAP(Dry Season) OF STUDY AREA

Fig.7: Distribution of $\mathrm{CH}_{4}$ in the Study Area in the Dry Season 
Distribution of TSP in the Study Area in the Dry Season In the dry season, TSP hotspots are visible within an extended area of Obio/Akpor and Eleme followed by Port Harcourt with highest concentration within $716.27 \mu \mathrm{g} / \mathrm{m}^{3}$ to $792.81 \mu \mathrm{g} / \mathrm{m}^{3}$ as shown in Figure 8. It occupies elongated aerial coverage of 26,466 meters length. It has a larger influence on Ikwerre followed by Oyigbo and showed its moderate influence on Etche area. It is predicted that these hotspots will contribute additional $2.0 \mu \mathrm{g} / \mathrm{m}^{3}$ to $3.4 \mu \mathrm{g} / \mathrm{m}^{3}$ to the background concentration of TSP in parts of Ikwerre, Oyigbo and Etche.

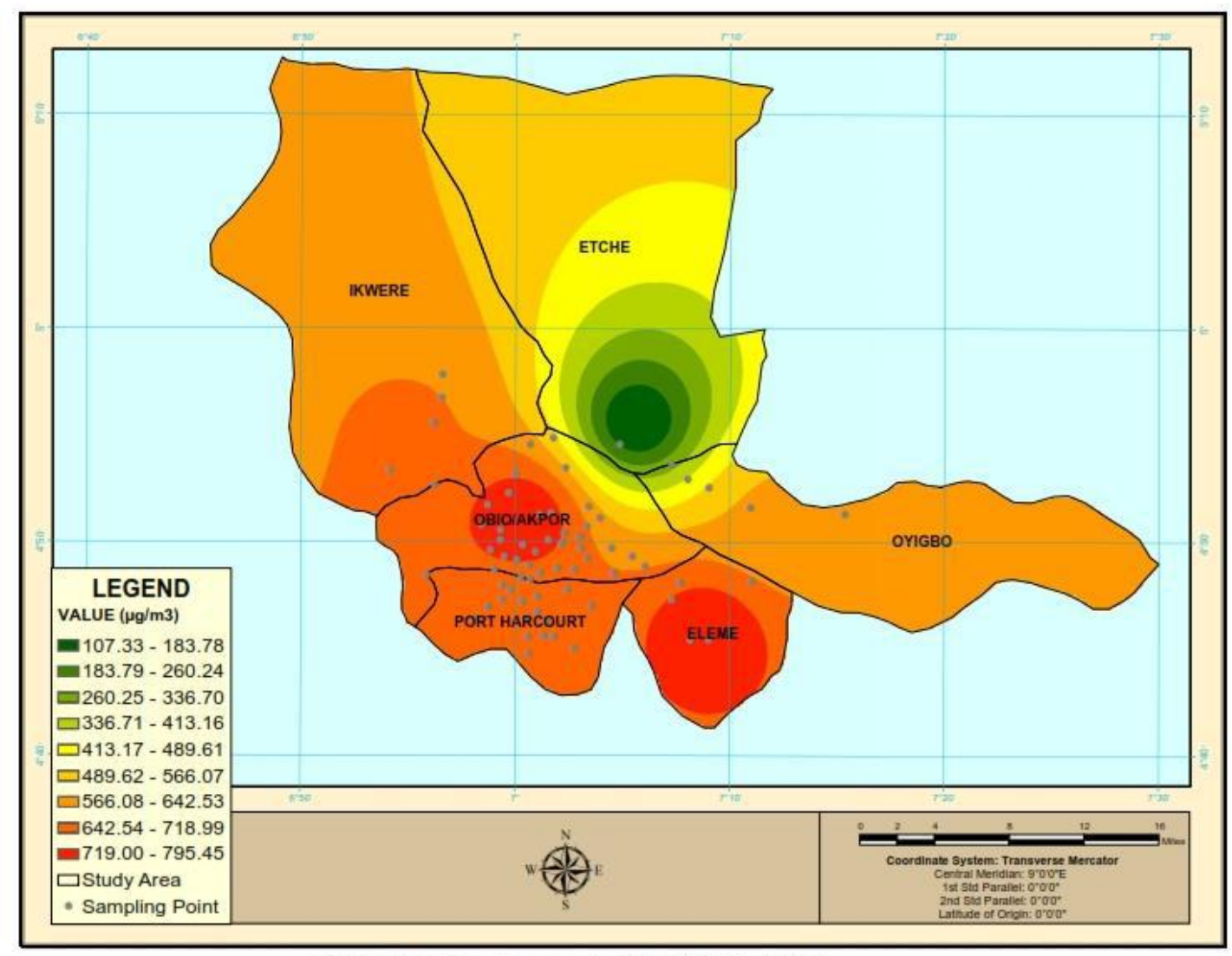

TSP MAP(Dry Season) OF STUDY AREA

Fig.8: Distribution of TSP in the Study Area in the Dry Season

\section{Distribution of PM10 in the Study Area in the Dry Season}

In the dry season, $\mathrm{PM}_{10}$ hotspots are visible within an extended area of within Obio/Akpor and Eleme followed by Port Harcourt with highest concentration within $501.39 \mu \mathrm{g} / \mathrm{m}^{3}$ to $554.09 \mu \mathrm{g} / \mathrm{m}^{3}$ as shown in Figure 9. It occupies elongated aerial coverage of 27200 meters length. It has a larger influence on Oyigbo but less on Ikwerre and Etche. It is predicted that these hotspots will contribute about $10 \mu \mathrm{g} / \mathrm{m}^{3}$ to $25 \mu \mathrm{g} / \mathrm{m}^{3}$ to the background concentration of $\mathrm{PM}_{10}$ in parts of Oyigbo, Ikwerre and Etche. 


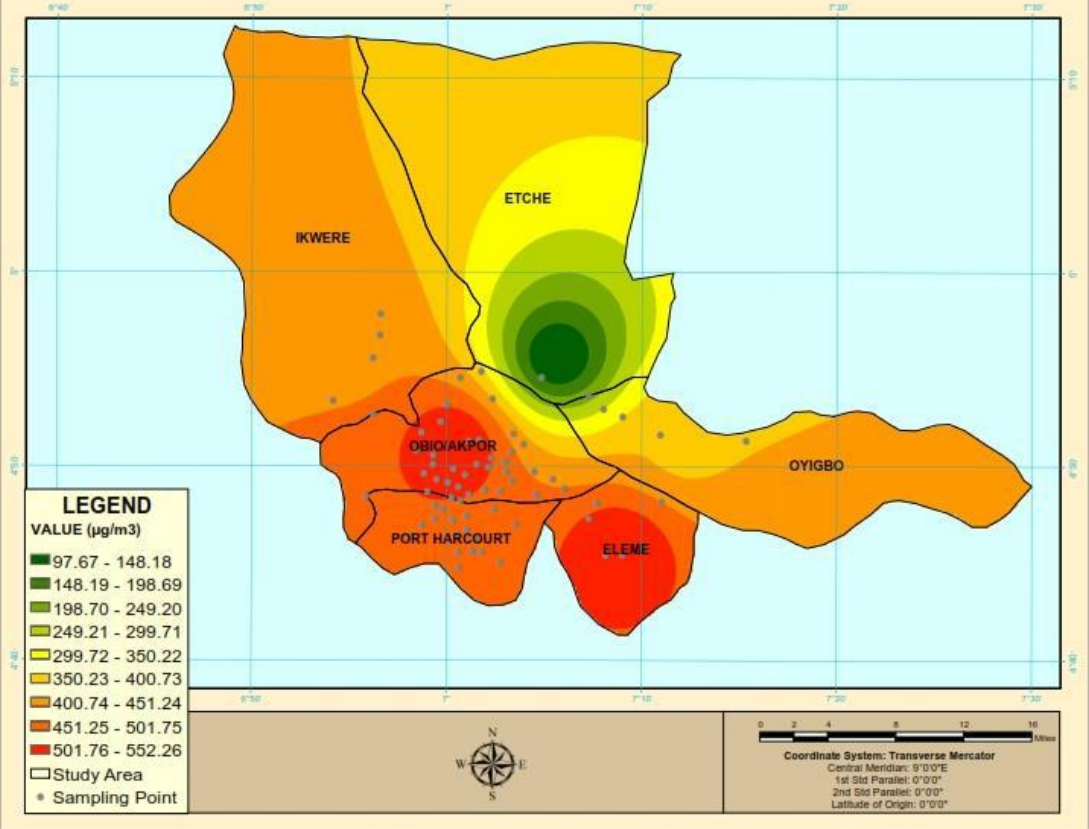

PM10 MAP(Dry Season) OF STUDY AREA

Fig.9: Distribution of PM $M_{10}$ in the Study Area in the Dry Season

Distribution of $\mathbf{P M}_{2.5}$ in the Study Area in the Dry Season

In the dry season, $\mathrm{PM}_{2.5}$ hotspots are visible within Eleme followed by Port Harcourt and Obio/Akpor with highest concentration within $84.15 \mu \mathrm{g} / \mathrm{m}^{3}$ to $92.19 \mu \mathrm{g} / \mathrm{m}^{3}$ as shown in Figure 10. It occupies an aerial coverage of 4100 meters radius. It has a larger influence on Ikwerre and Oyigbo, but least influence on Etche area. It is predicted that these hotspots contribute about $3.5 \mu \mathrm{g} / \mathrm{m}^{3}$ to $5.5 \mu \mathrm{g} / \mathrm{m}^{3}$ to the background concentration of $\mathrm{PM}_{2.5}$ in parts of Ikwerre, Oyigbo and Etche,

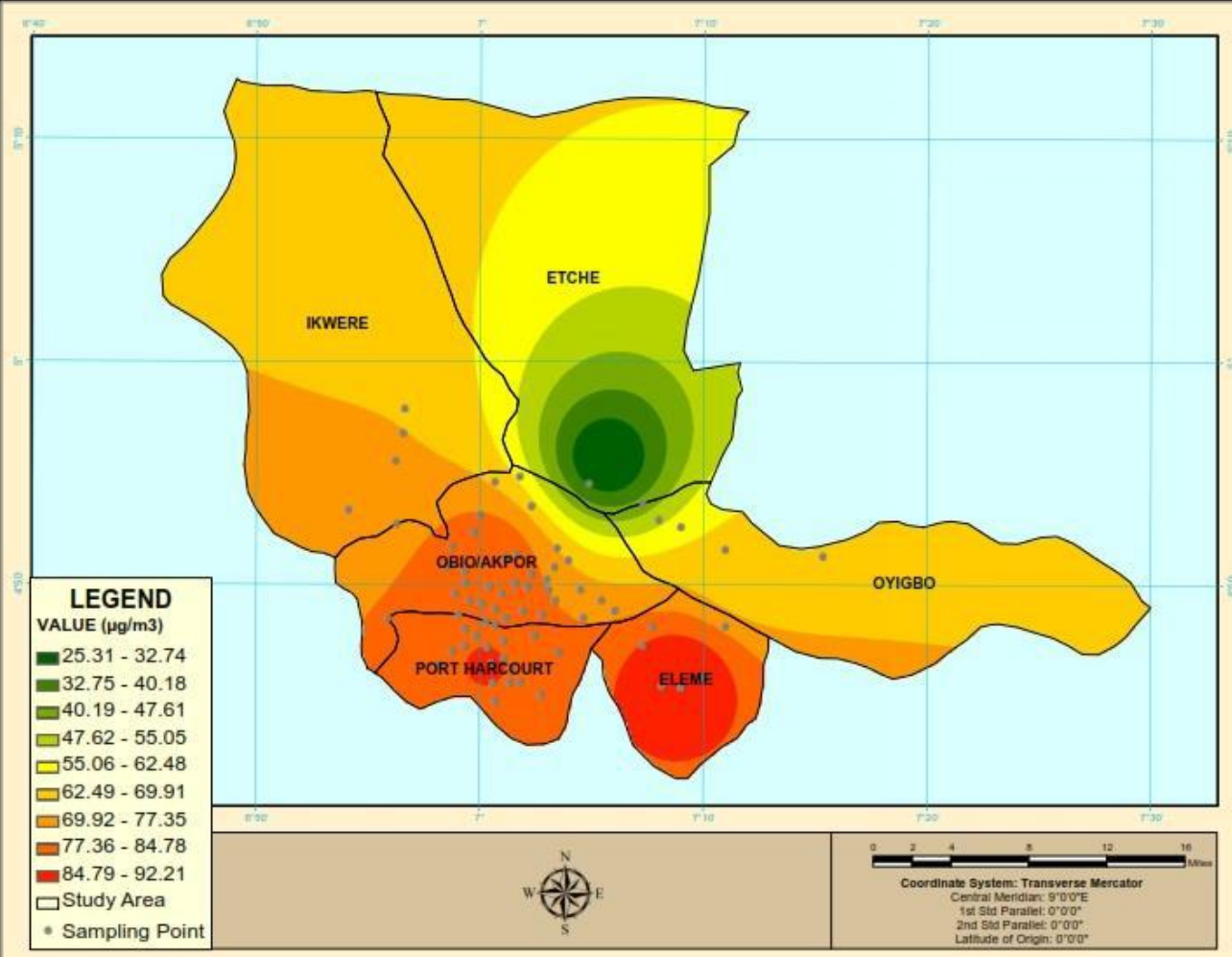

PM2.5 MAP(Dry Season) OF STUDY AREA

Fig.10: Distribution of PM 2.5 in the Study Area in the Dry Season 


\section{DISCUSSION}

Evaluation of Pollutants Dispersion Pattern in the Study

\section{Area in the Dry Season}

The pollutants dispersion patterns in the study area in the dry season were evaluated with the aid of pollution roses and bivariate polar plots of each pollutant with respect to wind speed and wind direction. The dry season results are presented in Figures $11(\mathrm{a}-\mathrm{j})$ and $12(\mathrm{a}-\mathrm{j})$. The pollution roses and polar plots were developed using the mean concentration of each pollutant in different wind speed and percentage frequency count of wind direction categories (Munir, 2016). They were simulated with the aid of Generalized Additive Model (GAM) smoothing techniques Carslaw, (2015) that depict pollutant concentrations as a continuous surface.

Pollution roses (Figure $11(\mathrm{a}-\mathrm{j})$ ) showed that pollutant concentrations increase with increased wind speed. Low concentrations of pollutants were obtained at low wind speed and vice-versa. This implies that wind speed has positive influence on the concentration levels of pollutants in the study area.
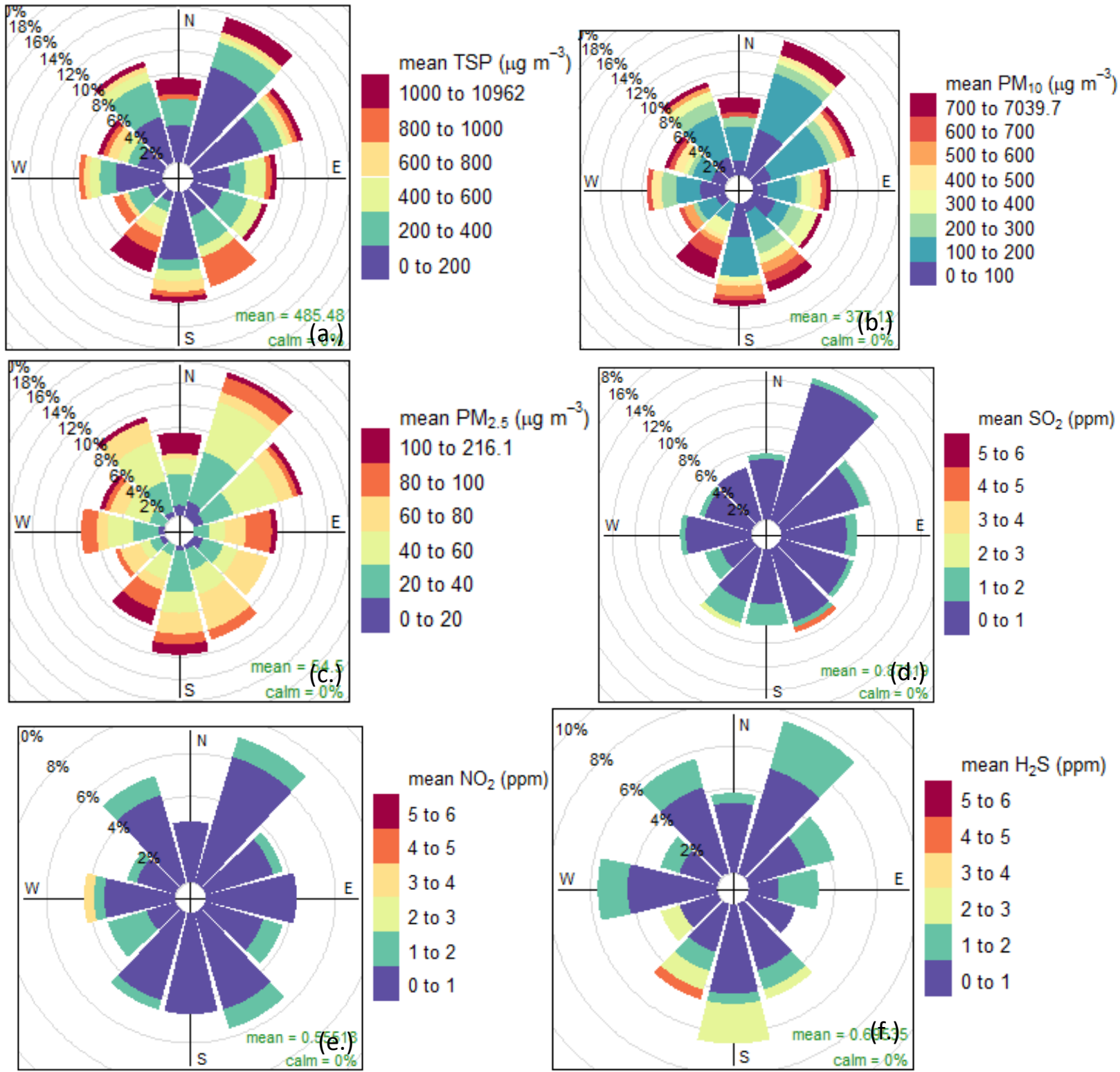

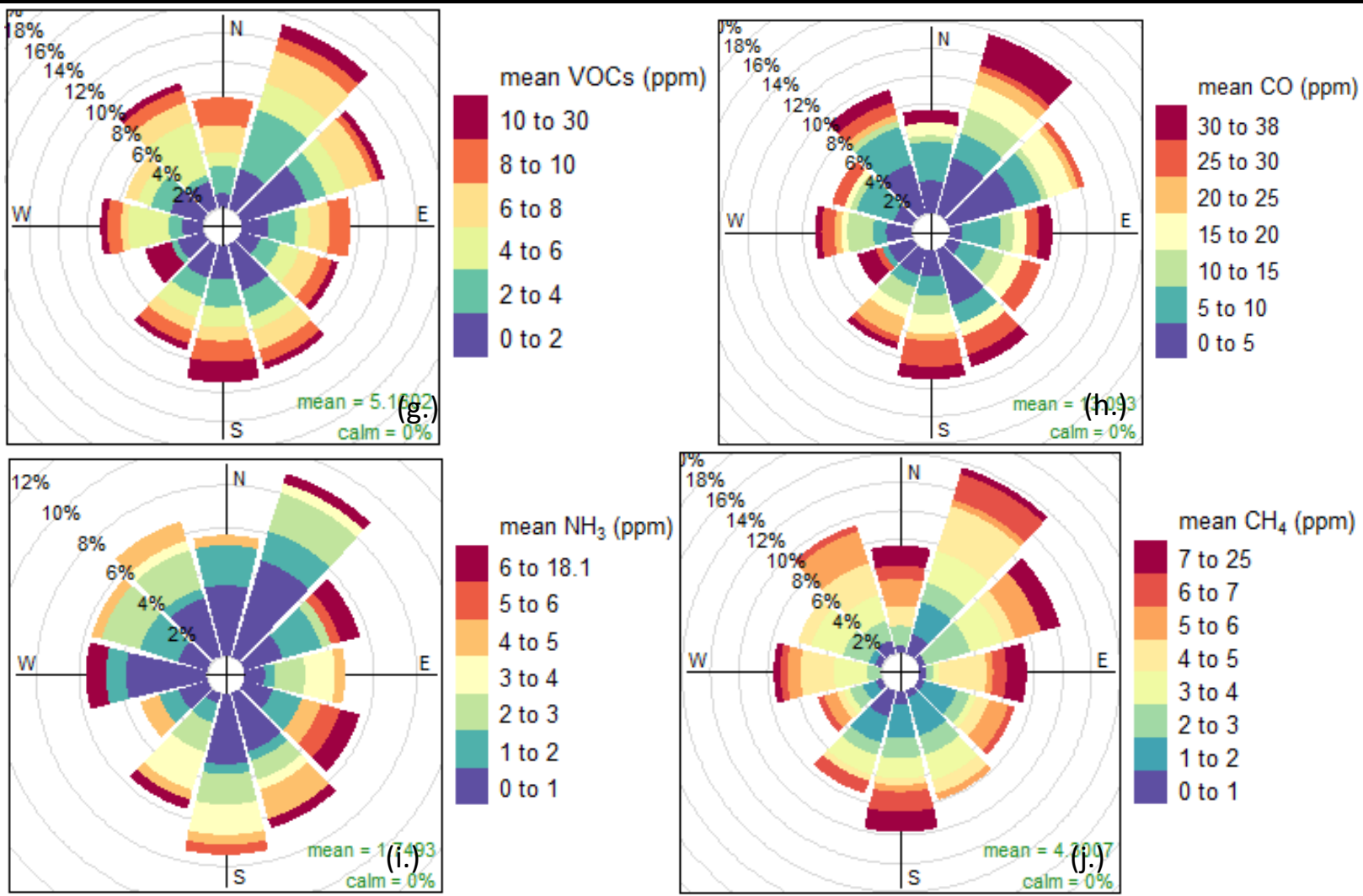

Fig.11(a-j): Pollution Roses of Pollutants in the Study Area in the Dry Season

The pollutant polar plots (Figure $12(\mathrm{a}-\mathrm{j})$ ) showed that concentrations of pollutants in the area are associated with wind speed up to $3.5 \mathrm{~m} / \mathrm{s}$. It is also observed from Figure 12 (a-j) that pollutant concentrations increase with increased wind speed.

Surface polar plots of pollutants concentrations in the study area revealed that high concentrations of $\mathrm{SO}_{2}, \mathrm{NO}_{2}, \mathrm{NH}_{3}$, $\mathrm{H}_{2} \mathrm{~S}$ and VOCs are associated with the south-west and southeast directions and are dispersed toward the north-east and north-west directions. This may imply that sources of these pollutants are in the southern part, which is the coastal region of the study area. Industrial activities, especially in Eleme area (refineries, petrochemical company, fertilizer companies, industrial waste management facilities, civil construction, gas flaring, and vehicular movement) and the release of black carbon (black soot) due to illegal refineries in the coastal area may be the sources of these pollutants (Ahove, 2006, Akpan et al., 2014 and Antai et al., (2016)).

Figure 12 (a-j) also indicate that concentrations of $\mathrm{CO}$ is associated with south-west, south-east and north-east directions and are dispersed toward the north-west directions. This may imply that sources of this pollutant are both in the southern and northern parts, which are the coastal and upland areas. Industrial activities, vehicular exhaust emissions, gas flaring and oil and gas exploitation in Eleme, Port Harcourt, Obio/Akpor and Etche areas might be the sources of these pollutant (Bhatia, 2011, Bleta et al., 2017, Efe, 2005 and Emmanuel et al., 2009) .

Similarly, concentrations of Methane $\left(\mathrm{CH}_{4}\right)$ and Particulate matter (TSP, $\mathrm{PM}_{10}$ and $\mathrm{PM}_{2.5}$ ) are associated with both northern and southern directions. This showed that activities in the both the coastal and up-land areas are responsible for the release of these pollutants into the environment. In other words, industrial activities, vehicular exhaust emissions, civil construction, the released of black carbon (black soot) due to illegal refineries in the coastal area, gas flaring and oil and gas exploitation in Eleme, Port Harcourt, Obio/Akpor, Etche and Ikwerre areas may be the sources of $\mathrm{CH}_{4}$ and Particulate matter in the air environment of the study area in the dry season period. 

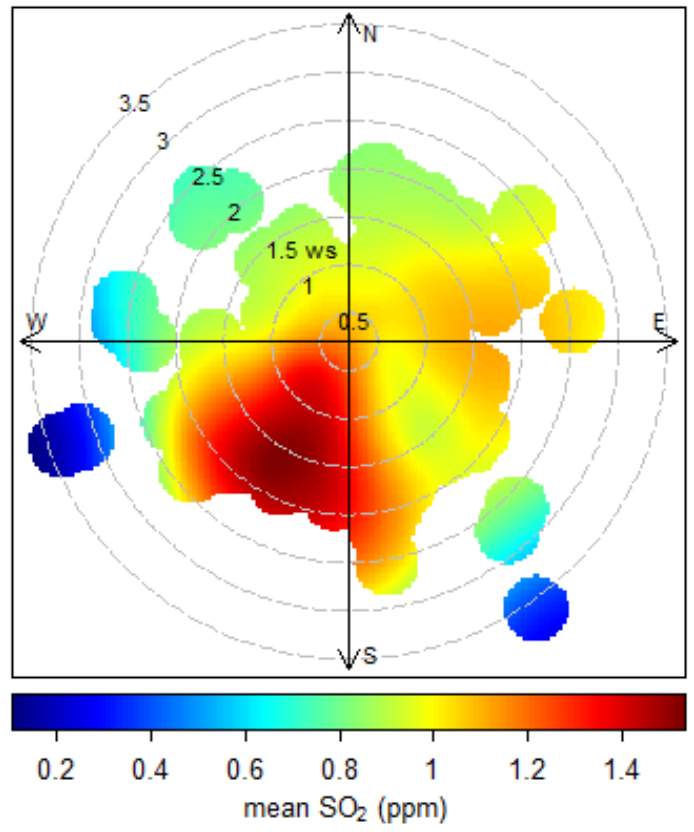

(a.)

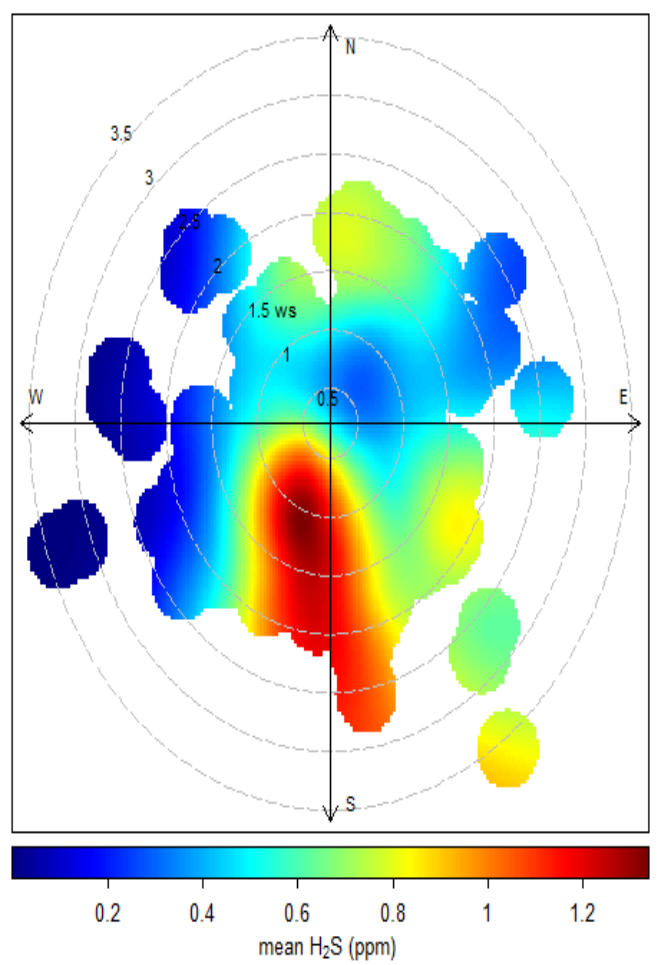

(c.)

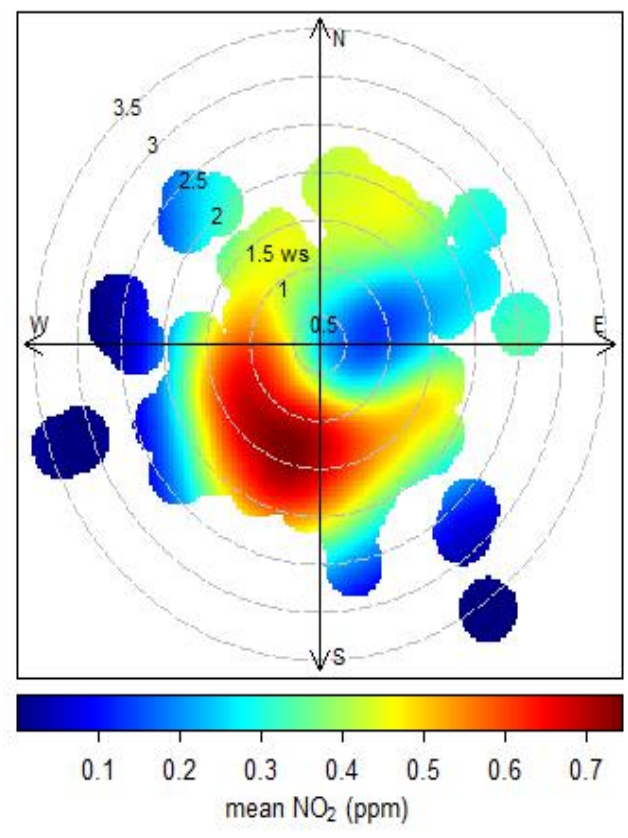

(b.)
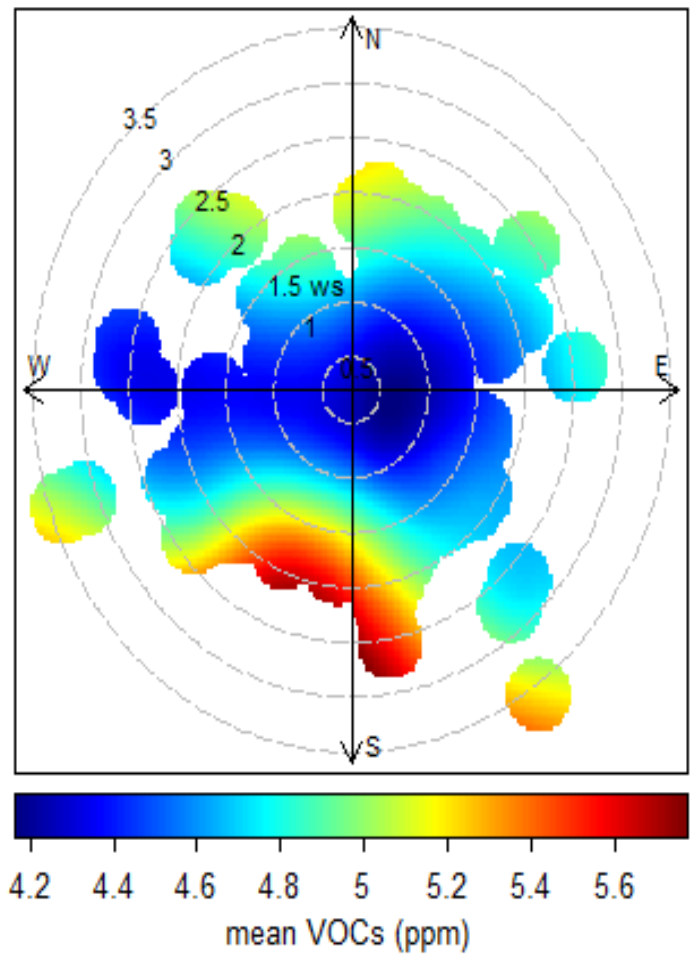

(d.) 


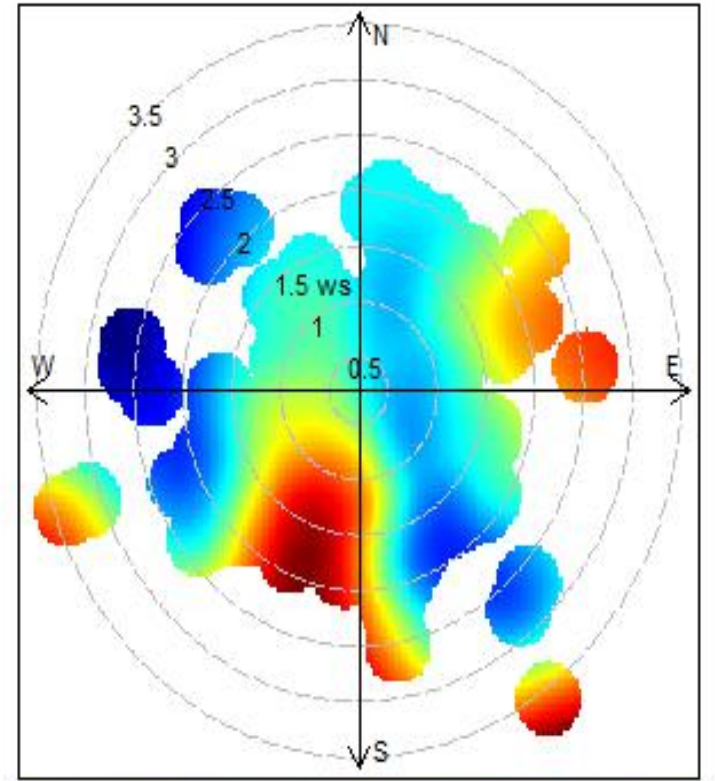

(e.)
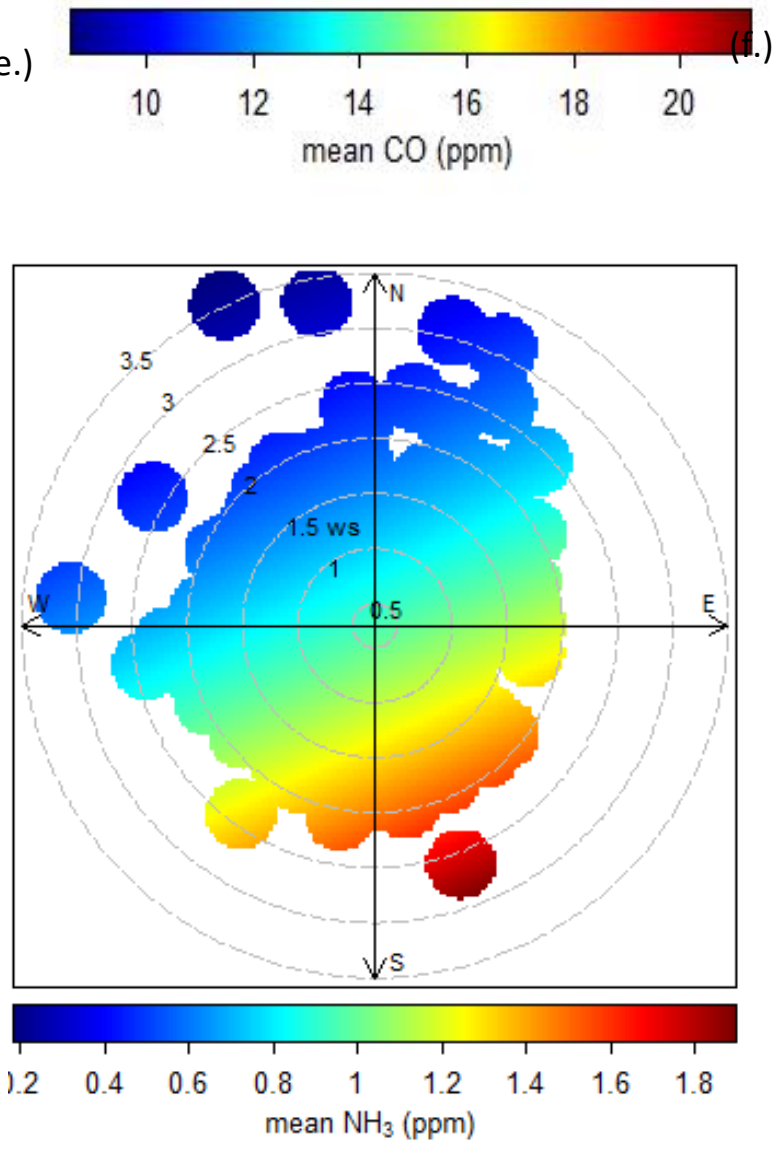

(g.)
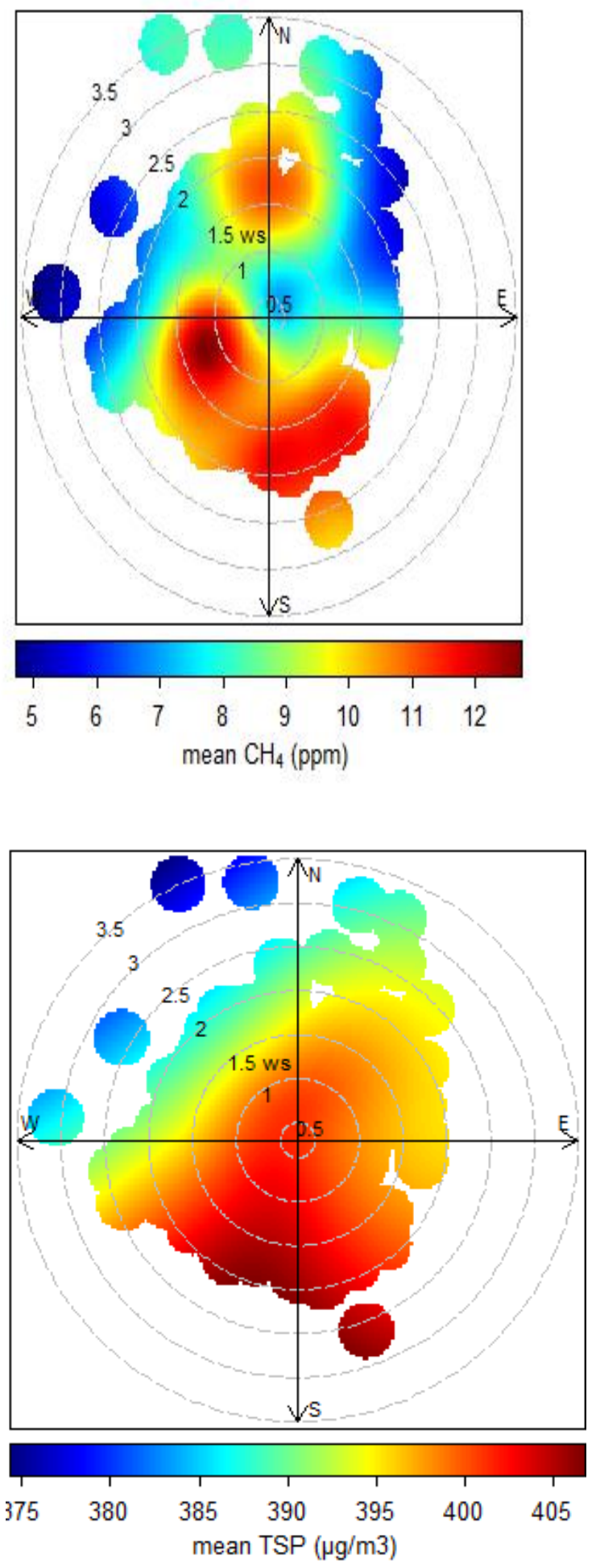

(h.) 


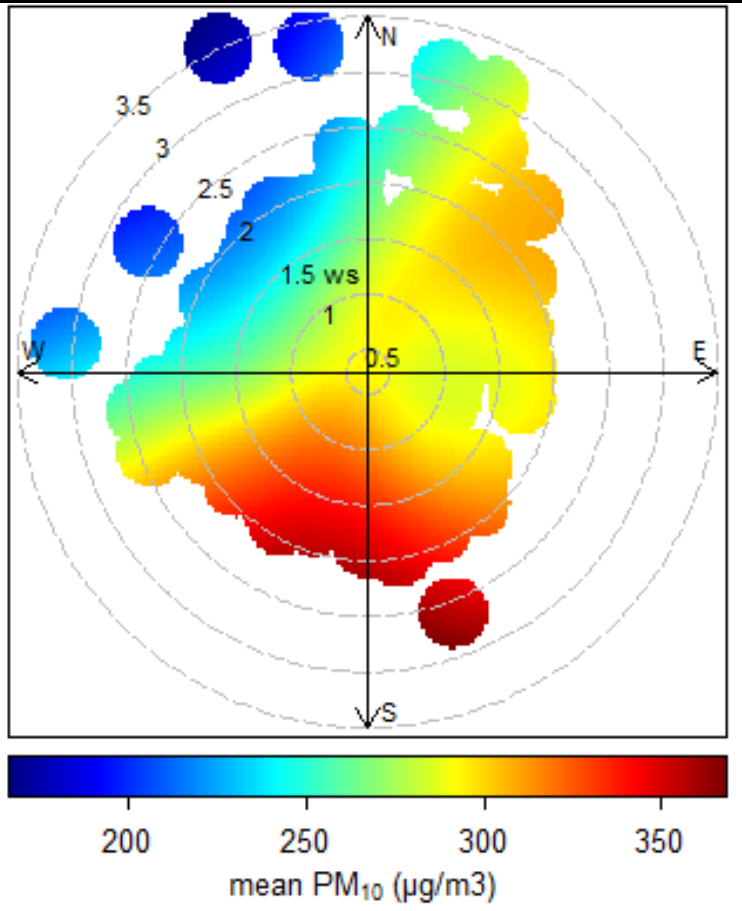

(j.)

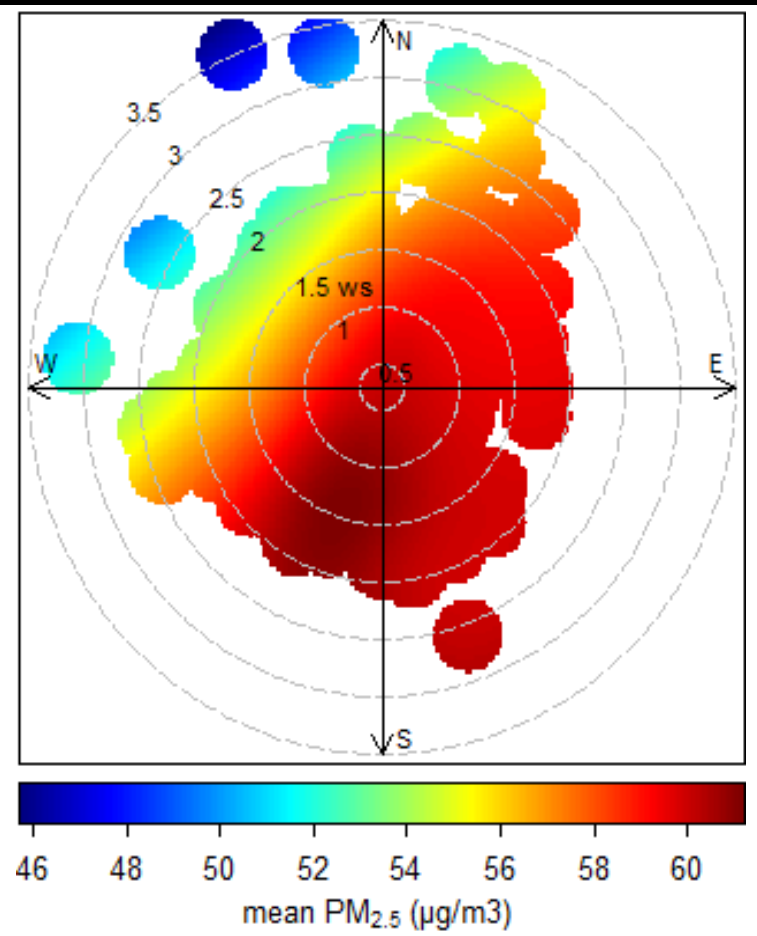

(i.)

Fig. 12 (a-j): Polar Plots of Pollutants in the Study Area in the Dry Season

\section{Determination of Particulate Ratio (TSP: $\mathbf{P M}_{10}: \mathbf{P M}_{2.5}$ ) in} the Dry season

Particulate mass concentration ratios $\mathrm{PM}_{10} / \mathrm{TSP}$ and $\mathrm{PM}_{2.5} / \mathrm{PM}_{10}$ in the dry season were determined in the modeling process. Result (Figure $13(\mathrm{a}-\mathrm{b})$ ) indicates that the mean mass concentration ratio of $\mathrm{PM}_{10} \mathrm{TSP}$ was 0.84 , while the mean mass concentration ratio of $\mathrm{PM}_{2.5} / \mathrm{PM}_{10}$ was 0.30 . This reveals that $\mathrm{PM}_{10}$ constitutes $84 \%$ of the concentration of total suspended particulate (TSP) measured in the study

\section{$\mathrm{PM}_{10} / \mathrm{tsp}$ ratio}

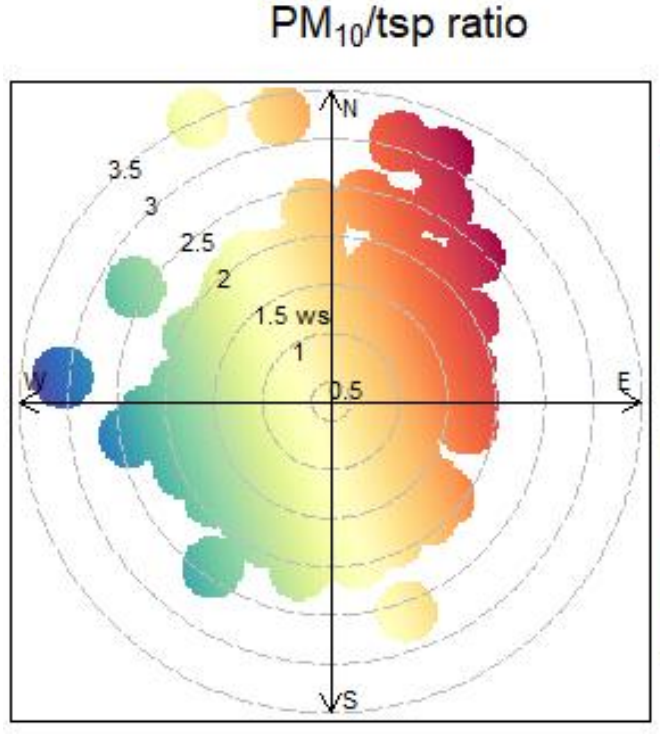

(a.)

Fi area, out of which $30.0 \%$ is composed of $\mathrm{PM}_{2.5}$. The $\mathrm{PM}_{2.5} / \mathrm{PM}_{10}$ ratio obtained in the dry season is below the range (0.5-0.8) found in urban areas of developing countries by World Health Organization (WHO, 2006). This $\mathrm{PM}_{2.5} / \mathrm{PM}_{10}$ ratio could be considered hazardous to human health. It revealed that black smoke emanating mostly from the combustion of hydrocarbon fossil fuel is concentrated in this fine fraction of particulate.
$\mathrm{PM}_{2.5} / \mathrm{PM}_{10}$ ratio

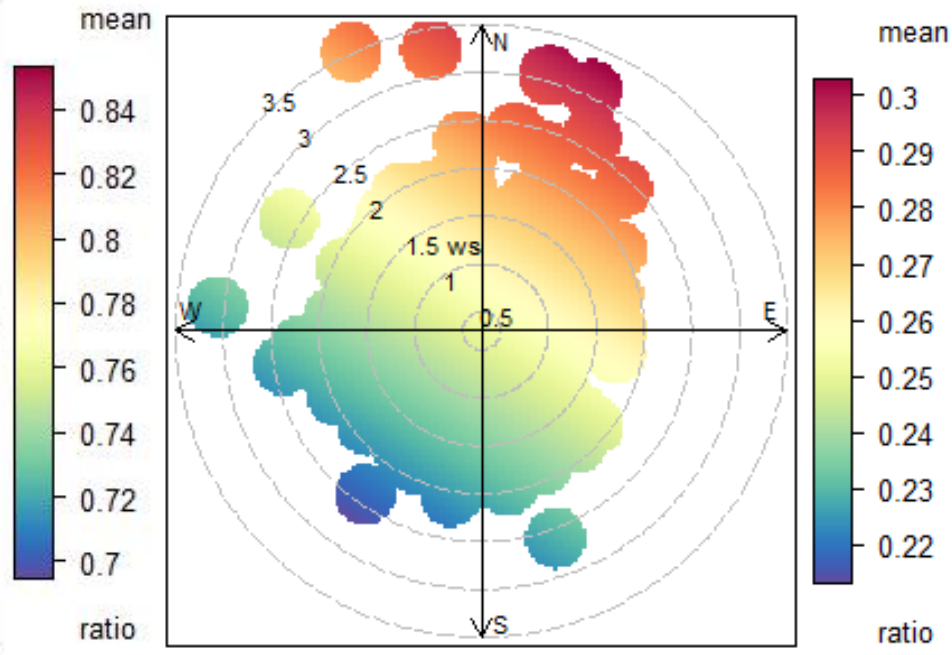

(b.) 


\section{CONCLUSION}

There were relatively high concentrations of air pollutants especially dominated in southern area in the dry season. Results of geospatial analysis and generalized additive models revealed that sources of pollutants in the study area are localized in the up-land area and region around the coastal area and dispersed towards the southern and northern parts of the study area in the dry season.

\section{REFERENCES}

[1] Ahove, M.A.N. (2006). The Nigerian Environment, National Open University of Nigeria, Lagos. Reagent Printing and Publishing Co. P 213.

[2] Akpan, P.E, Usip, E.E and Jeremiah, U.O (2014). Impacts of Traffics Volumes on Air Quality in Uyo Urban, Akwa Ibom State, Nigeria. Journal of environment and earth science. (21) $189-2000$.

[3] Antai, R. E., (2017). Urban Air Pollution Evaluation and Mitigation: A Case Study of Uyo City, Niger Delta, Nigeria. International Journal of Science Inventions Today. 6 (2), 036-048. March-April.

[4] Antai, R. E., Osuji, L. C. and Beka, F. T. (2016). The Impact of Air and Noise Pollution: A case study of Uyo Metropolis, Akwa Ibom State, Nigeria. International Journal of Science Inventions Today. 5 (5) 402-414, September-October.

[5] Bhatia, S.C. (2011). Environmental Chemistry Satish Kuma Jain New Delhi, India.

[6] Bleta, A., Nastos, P. T., Kaminski, U., and Dietze, V., (2017). Impacts of Coarse Atmospheric Particulate Matter Between 2.5 and $80 \mu \mathrm{m}$ on Respiratory Admissions in Heraklion, Crete Island, Greece. Springer International Publishing Switzerland. Springer Atmospheric Sciences, DOI: 10.1007/978-3319-35095-0_160, pp. 1117-1122.

[7] Carslaw, D.C. (2015). The Open Air Manual - OpenSource Tools for Analyzing Air Pollution Data. Manual for Version 1.1-4, King's College London.

[8] Efe, S.I., (2005). Urban Effects on Precipitation Amount, Distribution and Rain Water Quality in Warri Metropolis. Ph.D. Thesis, Dept of Geography and Regional Planning Delta State University Abraka, Delta State Nigeria. 2-47.

[9] Emmanuel, .E .E, Justina, .E.U, Felix, .E, Justice, .I.O., and Dike, O., (2009). Spatial and Diurnal Variations of Carbon monoxide (CO) Pollution from Motor Vehicles in an Urban Centre. Journal of Environmental Studies. 19(4), 817-823.
[10] Esplin, G.L., (1995) Approximate Explicit Solution to the General Line Source Problem. Atmospheric Environment. (29), 1459-1463

[11] Everitt, R, R. (1992). Environmental Effects Monitoring Manual. Prepared for the Federal Environmental Assessment Review office and Environment Canada, Environmental Assessment Division, Inland Waters Directorate, Ottawa, CN.

[12] Munri, S. (2016); Modeling the Non-Linear Association of Particulate Matter $\left(\mathrm{PM}_{10}\right)$ With Meteorological Parameters and Other Air Pollutants-A Case study In Makkah. Arabian Journal of Geosciences.

https://Www.Researchgate.Net/Publication/28738766 